Summer 7-22-2021

\title{
Reducing the Incidence of Compassion Fatigue in Obstetrical Nurses
}

\author{
Naveen Samuel \\ University of St. Augustine for Health Sciences, n.samuel@usa.edu
}

DOI: https://doi.org/10.46409/sr.QMBM9010

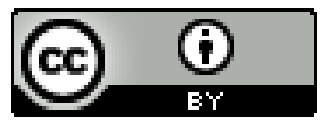

This work is licensed under a Creative Commons Attribution 4.0 License.

Follow this and additional works at: https://soar.usa.edu/scholprojects

Part of the Psychiatric and Mental Health Nursing Commons

\section{Recommended Citation}

Samuel, N. (2021). Reducing the Incidence of Compassion Fatigue in Obstetrical Nurses. [Doctoral project, University of St Augustine for Health Sciences]. SOAR @ USA: Student Scholarly Projects Collection. https://doi.org/10.46409/sr.QMBM9010 


\section{Reducing the Incidence of Compassion Fatigue in Obstetrical Nurses}

Naveen Samuel, MS, ARNP, ANP-BC, FNP-BC

School of Nursing, University of St. Augustine for Health Sciences

This Manuscript Partially Fulfills the Requirements for the

Doctor of Nursing Practice Program and is Approved by:

Camille Payne, $\mathrm{PhD}, \mathrm{RN}$

Beverly B. McInnis, DNP, RNC, CNS

Approved: July 22, 2021 


\begin{abstract}
Practice Problem

Compassion fatigue is a growing problem that can affect $21 \%$ to $39 \%$ of nurses who work in hospital settings (Berger et al., 2015). Compassion fatigue has been further exacerbated due to the COVID-19 pandemic. Compassion fatigue negatively impacts the nurses in profound physical and emotional ways.
\end{abstract}

\title{
PICOT
}

The PICOT question that guided this project was: For obstetrical nurses working in a nonprofit organization, what is the effect of a compassion fatigue program, compared with no program, on nurses in reducing compassion fatigue after two months?

\section{Evidence}

Current evidence shows that mindfulness decreases compassion fatigue and increases compassion satisfaction.

\section{Intervention}

This paper describes how a mindfulness program was implemented in obstetrical unit in a nonprofit hospital in central Virginia.

\section{Outcome}

The implementation of this mindfulness program has resulted in a $15.6 \%$ increase in compassion satisfaction, a $35.1 \%$ decrease in burnout, and a $39.5 \%$ decrease in secondary traumatic stress.

\section{Conclusion}

This EBP project demonstrated that the mindfulness program successfully decreased the incidence of compassion fatigue in obstetrical nurses at a statistically significant level. 


\section{Reducing the Incidence of Compassion Fatigue in Obstetrical Nurses}

The term "compassion fatigue" (CF) was first coined in the 1950s in nursing and with other first line responders (Milligan \& Almomani, 2020). CF was introduced by Joinson (1992), where she described $\mathrm{CF}$ as a unique form of burnout (BO) influencing individuals in care giving careers including pastors, advisors, and particularly nurses. Critical care nurses provide care to highly critical patients and are at higher risk to develop CF (Sacco et al., 2015).

This evidence-based practice (EBP) project examines the problem of CF in nurses who work in obstetrical units. The aim of this scholarly project is to reduce the incidence of $\mathrm{CF}$ through the implementation of a CF program which increases awareness and compassion satisfaction through practicing mindfulness. This paper discusses the significance of the practice problem; PICOT question; theoretical framework; evidence search strategy and results; themes with practice recommendations; setting, stakeholders, and system change; implementation plan with timeline and budget; evaluation plan; impact; dissemination plan; and conclusion.

\section{Significance of the Practice Problem}

Figley (1995) defined CF as "the natural consequent behaviors and emotions resulting from knowing about a traumatizing event experienced by a significant other, for example, the stress resulting from helping or wanting to help a traumatized or suffering person" (p. 253). CF in nurses is well documented in literature (Hooper et al., 2010; Hunsaker et al., 2015; Mooney et al., 2017; Notle et al., 2017; Wu et al., 2016) and develops gradually from an undesired result of taking care of suffering individuals (Stamm, 1999). Moreover, CF is an emotional and physical fatigue that can be preventable when balanced by compassion satisfaction (Hunsaker et al., 2015). 
CF can manifest itself through the following symptoms: sleep disturbance, trouble concentrating, anxiety, stress, negative attitudes, muscle tightness, feeling troubled, exhausted, overpowered with sadness, along with withdrawal that may have a negative impact on productivity (Milligan \& Almomani, 2020; Notle et al., 2017). Other outcomes of CF are a diminished feeling of satisfaction, powerlessness, disappointment, and an absence of inspiration (Harris \& Quinn Griffin, 2015). CF is a topic that has grown in its popularity over the past 20 years due to the challenges that nurses face in their profession (Notle et al., 2017). CF may lead to increased temper, irritability, and negative adapting practices including alcohol and illicit drug usage (Coker \& Joss, 2016; Jarrad et al., 2018; Kelly et al., 2015; Substance Abuse and Mental Health Services Administration [SAMHSA], n.d.). CF may lead to decreased productivity, increased medical errors, and decreased patient satisfaction (Berger et al., 2015). CF in nurses leads to nearly $20 \%$ of nurses leaving their jobs within their first year (Kelly \& Todd, 2017).

According to Berger et al. (2015), CF can affect $21 \%$ to $39 \%$ of nurses who work in hospital settings. According to Nursing Solutions Inc. (2020), the cost of a nurse turnover ranges from approximately $\$ 33,000$ to $\$ 56,000$, which adds to a total loss of three to six million dollars per year in the United States. A high level of CF is associated with a high rate of patient mortality (Welp et al., 2015) and acquired hospital infection (Cimiotti et al., 2012). In the nonprofit organization where this evidence-based practice project took place, the chief nursing officer expressed a concern that nurses are experiencing a higher level of compassion fatigue during the COVID-19 pandemic. Therefore, there was a need to address this issue.

Healthcare organizations offering support and a healthy environment for their nurses increases nurse satisfaction, improves patient outcomes, decreases nurse turnover, and reduces healthcare costs (Kelly \& Todd, 2017; Wu et al., 2016). CF and compassion satisfaction (CS) 
should be assessed on a regular basis, and nurses should be encouraged to promote self-care and engage in leisure time (Polat et al., 2020).

\section{PICOT Question}

The PICOT question for the evidence-based project is: for obstetrical nurses working in a nonprofit organization (P), what is the effect of a CF program (I), compared with no program (C), on nurses in reducing $\mathrm{CF}(\mathrm{O})$ after 2 months $(\mathrm{T})$ ?

\section{Population}

Obstetrical nurses serve as the target population of the study. Nurses who are 18 years and older are included in the EBP.

\section{Intervention}

The implementation of a CF policy and procedure was the intervention. The components of the CF program consist of the "Professional Quality of Life" ("ProQOL") surveys and tools, a PowerPoint presentation on CS and CF, and sustainable daily mindfulness practices for staff. All obstetrical nurses will receive the intervention; the comparison will be the results of the ProQOL survey that will be taken before and after receiving the program.

\section{Comparison}

The intervention was compared to the current practice.

\section{Outcome}

The primary outcome measure in this EBP was to reduce the incidence of $\mathrm{CF}$ and increase CS.

\section{Time}

After receiving approval from the EBP Project Review Council (EPRC) at the University of Saint Augustine and from the Institutional Review Board (IRB) of the non-profit healthcare 
organization, the implementation began with a pre-test. A post-test was conducted at the end of the 4-week project.

\section{Evidence-Based Practice Framework and Change Theory}

The Johns Hopkins Nursing Evidence Based Practice Model (JHNEBP) model was developed by nurse leaders from both Johns Hopkins Hospital and Johns Hopkins University School of Nursing (White et al., 2016). The JHNEBP model offers a critical thinking approach to develop a practical model to facilitate the ability of nurses to implement the most updated evidence and translate it into practice (Johns Hopkins Medicine, n.d.).

The JHNEBP model was planned explicitly to address the needs in the nursing profession by utilizing a three-step process: practice question, evidence, and translation (PET) (White et al., 2016). The objective of the model is to ensure that the most updated research and best practices are rapidly and suitably applied to patient clinical care (Johns Hopkins Medicine, n.d.).

The JHNEBP model, which provides the use of a scale for categorizing and rating the literature, ensures that the selection of articles regarding CF will reflect quality research to include in the EBP project (White et al., 2016). The EBP project took place in a magnet hospital that maintains the requirements of the American Nurses Credentialing Center. The fundamentals of the culture of a magnet hospital are to demonstrate strong nursing leadership, keep nurses engaged, and build a resilience in the workplace by reducing CF and increasing CS (Graystone, 2019). The strong organizational leadership and culture, which trusted the EBP and supported it to reach the common goal of achieving the best patient outcomes, contributed to the success of the project (Dearholt \& Dang, 2012).

The JHNEBP model was utilized as guidance through its main three components, PET, and the 18 total steps within the practice question, evidence, and translation (Dearholt \& Dang, 
2012). The first component was the practice question which included five steps: recruit a multidisciplinary team, compose and refine the EBP PICOT question, identify stakeholders, assign responsibility for leadership, and arrange time for team meetings (Dearholt \& Dang, 2012). The second component was the evidence which included five steps: perform a search for evidence, appraise the level of each part of the evidence, combine the evidence, synthesize the strength and quality of evidence, and create a proposal for change based on the levels of synthesis (Dearholt \& Dang, 2012). The literature search helped identify the training material and module for CF. The third component was the translation which included eight steps: decide the practicality and achievability of recommendations, develop an action plan, acquire resources to implement the action plan, execute the action plan, assess results, report results to stakeholders, specify the future steps, and disseminate the results (Dearholt \& Dang, 2012). The key stakeholders assisted the project manager in determining the timeline, the best time and method to present the protocol that would best fit the flow of the hospital unit. The educational department and stakeholders are instrumental in sustaining the project in the future.

In this EBP project, Lewin's Change Theory was utilized to support the planned change and provided a framework for motivating acceptance of the intervention to reduce $\mathrm{CF}$ among nurses. Lewin's theory focuses on changing behaviors through a three-step approach which includes unfreeze, change, and refreeze (Mulholland, 2017). In the unfreezing phase, Lewin suggested that the old behavior must be changed in order for new behavior to be established (McGarr et al., 2012). The second step in Lewin's Change Theory is change, during which nurses and the organization adopt a new status of increased CS and resilience while reducing CF (Burnes, 2004). The third step in this theory is refreeze, which solidifies the new status of the behavior change. Refreeze requires patience and perseverance. During this step of the change 
model, the organization adopts the change to improve nurses' self-care and resilience and to sustain the reduction in CF (Burnes, 2004).

\section{Evidence Search Strategy}

An electronic search of digital databases utilizing the University of St. Augustine's library portal included: Cumulative Index to Nursing and Allied Health Literature Complete (CINAHL Complete), Public/Publisher MEDLINE (PubMed), Ovid Emcare, and PsycINFO. The key words used in the advanced search included: compassion fatigue, nurses, nursing staff, nurse, interventions, strategies, and best practices. The search limited the report-type to peerreviewed academic journals, in the publication English language, and within the time frame January 1, 2015 to present date October, 2020. A title search using the above key words and the above general limiters resulted in 537 titles from the four databases.

The search in CINAHL resulted in a total of 141 articles. Boolean operators were used to capture the best search: compassion fatigue AND nurses OR nursing staff OR nurse AND interventions OR strategies OR best practices. The search in PubMed resulted in 20 articles. The terms compassion fatigue AND nurses OR nursing staff OR nurse AND interventions OR strategies OR best practices were utilized. The search in Ovid Emcare resulted in 307 articles. The terms utilized were: compassion fatigue AND nurses. The search in PsycINFO resulted in 69 articles. The terms compassion fatigue AND nurses OR nursing staff OR nurse AND interventions OR strategies OR best practices were utilized.

\section{Evidence Search Results}

A total of 537 articles were carefully inspected to determine whether they met the inclusion criteria. This review was conducted following the Preferred Reporting Items for Systematic Reviews and Meta-Analyzes (PRISMA). Articles were excluded if they were 
published before 2015, if they were written in a language different than English, and if their target population was non healthcare professionals such as teachers, firefighters, or caregivers. Thirty duplicate articles were removed, and 300 articles were excluded as they focused solely on the prevalence of CF, CF risk factors, or non-healthcare professionals. The remaining 207 articles were evaluated, and 183 articles were excluded as they did not focus on CF, did not evaluate the effectiveness of a $\mathrm{CF}$ prevention or intervention program, or did not utilize a specific validated measure of $\mathrm{CF}$. The application of these inclusion and exclusion criteria resulted in a total of 14 articles. See Figure 1 for the PRISMA diagram.

The 14 articles were evaluated for level and quality based on JHNEBP (Dang \& Dearholt, 2017). One Level I, high quality Grade A article that was an experimental, randomized controlled trial (RCT) was found. No Level II articles were found. Seven articles were Level III, and two of those were high quality Grade A articles: a systematic review of a combination of RCTs and a non-experimental study with meta-analysis. The remaining five were good quality Grade B articles: exploratory pre-post interventional pilot study, explanatory quantitative study, mixed methods sequential design study, and two systematic reviews. The remaining four were Level V, with one being a high quality Grade A article: a training workshop for nurses. The remaining three were good quality Grade B articles: two pilot studies and one evidence-based program (Dang \& Dearholt, 2017). A summary of primary research and systematic reviews can be found in Appendices A and B. A table describing the level of the articles is in Appendix C.

\section{Themes from the Literature}

While reviewing the literature, several themes emerged that address the components of the PICOT question. A thorough evaluation of the literature is provided in the evidence table that includes the level and quality of evidence-based support in Appendix A and systemic reviews in 
Appendix B. A synthesis of 14 articles of high and good quality, which utilized ProQOL as a validated tool to measure $\mathrm{CF}$, concluded that increased awareness increases $\mathrm{CS}$ and reduces $\mathrm{CF}$. Eleven of the 14 good quality articles showed that increased awareness reduces CF and increases CS, while nine of the 14 showed that practicing mindfulness reduces CF and increases CS (see Appendix D).

\section{Compassion Fatigue and Compassion Satisfaction}

CF as a term represents the emotional, physical, and job-related impacts of spending one's energy over any period of time to provide compassionate, empathic care to others (Adimando, 2018; Craigie et al., 2016; Durkin et al., 2016; Klein et al., 2018; Sullivan et al., 2029; Yilmaz et al., 2018; Zajac et al., 2017). CF may lead to negative detrimental implications: physical, mental, and work-related consequences that affect healthcare quality and patient safety, and degree of commitment with one's workplace in a negative way (Adimando, 2019; Blackburn et al., 2020; Coetzee \& Klopper, 2010, as cited in Blackburn et al., 2020; Jenkins \& Warren, 2012, as cited in in Blackburn et al., 2020). CF is associated with a variety of adverse effects in the nursing profession, including psychological distress, decreased efficiency, increased absenteeism, and therefore the potential for increased risks to patient safety (Craigie et al, 2016; Yilmaz et al., 2018; Zajac et al., 2017). CF may lead to anxiety, depression, lack of ability to remain rational, mood lability, frustration, anger, and poor judgment. CF may lead to decreased retention of workers (i.e., increased turnover), decreased efficiency, increased work-related mistakes, and diminished employee satisfaction, all of which can contribute to substantial, but potentially preventable, costs for a company (Blackburn et al, 2020; Craigie et al, 2016; Sullivan et al, 2019; Yilmaz et al., 2018; Zajac et al., 2017). 


\section{Increased Awareness}

The most frequently cited intervention for reducing $\mathrm{CF}$ is increasing awareness of risk factors, causes, and symptoms of CF to empower nurses to identify and prevent its onset (Adimando, 2018; Blackburn et al., 2020; Craigie et al., 2016; Klein et al., 2018; OrtegaCampos, et al., 2020; Rajeswari et al., 2020; Sinclair et al., 2017; Sullivan et al., 2019; Wentzel \& Brysiewicz, 2017; Xu et al., 2020; Yilmaz et al., 2018). Several studies included workshops as a means of increasing staff awareness of CF and CS (Klein et al., 2018; Rajeswari et al., 2020; Sullivan et al., 2018; Zajac et al., 2017). Workshops ranged from 1 day to several weeks. Klein et al (2018) presented professional development programs to educate participants with a time range from 30 to 90 minutes. Sullivan et al. (2018) offered a one-time workshop to educate participants offsite on a retreat day.

\section{Mindfulness}

Mindfulness is described by Orellana-Rios (2017, as cited in Blackburn et al., 2020) as actively bringing consciousness with openness, receptivity, and interest to the here-and-now experience. The practice of mindfulness is opposite in purpose to the normal mentality of nurses and pride in multitasking. Intuition, concentration, and the induction of the calming response are combined through mindful practices (Caley et al., 2017, as cited in Blackburn et al., 2020).

Mindfulness is defined as "awareness that emerges through paying attention on purpose, in the present moment, and nonjudgmentally" (Kabat-Zinn 2003, p. 145).

Clinical studies demonstrated that mindfulness offers positive outcomes in minimizing depressive mood and stress, as well as avoiding depression while increasing self-compassion and positive behavior (Blackburn et al., 2020; Craigie et al., 2016; Khoury et al., 203, as cited in Craigie et al., 2016; Klein et al., 2018; Rajeswari et al., 2020; Sullivan et al., 2019). Mindfulness 
throughout the literature varies from 3 minutes to 10 minutes to 20 minutes per session (Craigie et al., 2016; Ortega-Campos et al., 2018; Rajeswari et al., 2020; Wentzel \& Brysiewicz 2017).

\section{ProQOL}

The ProQOL tool was first developed by Stamm and Figley in 1995 (Figley \& Stamm, 1996; Gentry, 2002; Stamm, 2010). ProQOL (version 5) is the most widely utilized validated tool as a pre/posttest to examine the effectiveness of the multidimensional intervention on reducing CF and increasing CS (Stamm, 2010). In general, high ratings of CS were associated with positive interaction with one's employer (Adimando, 2018; Blackburn et al., 2020; Craigie et al., 2016; Durkin et al., 2016; Michael et al., 2019; Rajeswari et al., 2020; Sullivan et al., 2019; Yilmaz et al., 2018; and Zajac et al, 2017).

\section{Practice Recommendations}

Based on the literature synthesis, the recommendation was to implement a nurse-centered CF reduction program. This includes presurvey using ProQOL-5, a CF program over 4 weeks, and a postsurvey using ProQOL-5. The program was made available to all nursing staff through their weekly newsletter. They were reminded by posters in the breakroom and flyers in the restrooms and locker rooms. There was an incentive of a drawing to select one participant to win a gift card. All participants, upon completion, received a self-care kit, including hand sanitizer, pen, and journal (Ortega-Campos et al., 2020; Wentzel \& Brysiewics, 2017).

\section{Project Setting}

The project setting was the obstetrical unit located in a 391 bed, non-profit Catholic healthcare system, with 11 labor rooms, and an obstetrical emergency department that includes two triage rooms and two operative suites. The obstetrical unit is composed of a mother/infant unit, women's surgical unit, as well as ante-partum and post-partum units. The mother infant unit 
has 21 private rooms, while the women's surgical unit is a 12 bed gynecology unit. This unit accommodates antepartum patients, as well as postpartum patients if needed. The non-profit organization delivers an average of 2000 births per year.

\section{Organizational Structure}

This hospital is a part of four campuses in the area. The hospital where the project took place is one of the oldest campuses in the area, serving approximately 1,230,852 residents from across 61 zip codes.

\section{Organizational Culture and Mission}

The hospital was built in 1966 by the community for the community. The hospital is a Center of Excellence for Minimally Invasive GYN surgeries as certified by the Surgical Review Corporation and was named by Style Weekly as the "best place in Richmond to have a baby." The hospital is the first community hospital in the area to achieve Magnet Recognition by the American Nurses Credentialing Center for nursing excellence. The mission of the hospital is to provide good help to those in need and to bring people throughout the region to health and wholeness.

\section{Organizational Need}

Organizational need for the project stemmed from the recommendation of the clinical nurse specialist of the Neonatal ICU and obstetrical unit, as well as the obstetrical unit director, to utilize the ProQOL validated tool to assess and recognize the early signs and symptoms of CF. The same tool measures compassion satisfaction, which are the pleasure and positive emotions derived from helping others, such as happiness, accomplishments, and satisfaction. 


\section{Organizational Support}

The organizational support was initially provided by the Clinical Nurse Specialist of the NICU and Obstetrical Units who formed a multi-disciplinary team to address the need to recognize and reduce $\mathrm{CF}$. The team included the unit director, chaplain, the clinical nurse specialist, and the social worker. The plan for sustainability for this project will be secured by the continued support and implementation of this project by the clinical nurse specialist of the unit. To sustain the EBP, a policy was created that requires an annual CF program. The start of this project created a micro system change, and the project will be adapted and utilized by other units, creating a meso system change.

\section{Stakeholders}

Brainstorming is the strategy and tool that was utilized to identify the stakeholders for this quality improvement evidence-based practice project. The following are the stakeholders: the nursing professional development coordinator, clinical care leaders, and the nurse director for the Obstetrical Unit. Project support was launched by inviting the stakeholders via a Zoom meeting to discuss the policy and procedure to reduce $\mathrm{CF}$.

\section{Strength, Weakness, Opportunity, and Threat Analysis}

An organizational Strengths, Weaknesses, Opportunities, and Threats (SWOT) analysis was conducted to assess the organization. The SWOT analysis provided an evaluation to determine the organization's readiness to implement the teamwork initiative (Agency for Healthcare Research and Quality, 2012). The SWOT analysis is provided in Appendix E. 


\section{Implementation Plan with Timeline and Budget}

\section{Project Objectives}

The EBP change reduces CF for obstetrical nurses by increasing CS. This aligns with the organization's mission to increase nurse awareness of CF and its early signs and symptoms and to create an intervention to mitigate its negative effect. The project's mission was to emphasize the nurses' wellbeing using mindfulness to increase resilience and therefore increase CS.

There are two main types of objectives: process objectives and outcome objectives. Process objectives focus on the activities to be finished in a particular time span (Centers for Disease Control and Prevention [CDC], n.d.). There are two process objectives. For details about the project's short-term and long-term objectives, see Appendix F.

Outcome objectives express the planned outcome or achievement of the program and the intervention (CDC, n.d.). They are regularly centered around changes in strategy, policy, system, knowledge, and behavior (CDC, n.d.). Outcome objectives can be short term, intermediate, or long-term objectives (see Appendix F).

\section{Project Plan}

The change model for this EBP project was Lewin's change model. Kurt Lewin was born in Poland in 1890. He was a pioneer in social, organizational, and applied psychology (Social Work Foot Prints, 2017). Lewin's change model is considered one of the cornerstone models for understanding organizational changes (Burnes, 2004). According to Bryant (2013), organizational culture is the product of beliefs, values, standards, and attitudes shared by individuals and groups that form the organization. Lewin's three stage model consists of the unfreezing, change, and refreezing states. 


\section{Unfreezing}

The unfreezing consists of creating the perception that change is needed and moving toward the new desired level of behavior. The goal in the unfreezing state is to create an awareness of how the status quo is hindering the individual and organization to create a desire to change (Wojciechowski et al., 2016). Increased awareness of CF and the need to recognize the early signs and symptoms to avoid physical, emotional, or psychological consequences on the individual level, as well as avoiding institutional consequences on the organizational level, was the first step towards the change. The ProQOL tool results for each individual nurse offered the actual status of CF and CS. The training program increased nurses' awareness of CF and CS. To justify the significance of the EBP and the need to address CF, a presentation was included in the staff meeting and available electronically due to the COVID-19 pandemic to increase staff and management awareness. This presentation provided the nurses with the reasons for the change and offered a roadmap for the intervention. The ProQOL survey was offered to all participants to assess the baseline CF and CS. A demographic questionnaire was answered individually at the same time.

\section{Change}

Change is the process that has to be carefully planned and executed (Manchester et al., 2014). During this step, individuals learn new behaviors, processes, and ways of thinking. Therefore, training, communication, support, and time are critical for nurses as they are becoming familiar with the change to achieve the desired outcomes.

The more nurses that were prepared for this step, the easier it was to complete and achieve the change. During this state, offering interventions such as mindfulness and organizational resources assisted nurses in striving and applying the change in their daily 
activities to resist CF and increase CS. During this phase, the result of the ProQOL survey was shared individually and as a unit. The unit champions placed flyers and reminders in the break room, restrooms and by the computers in the nursing station to remind and encourage nurses to participate in the weekly mindfulness intervention. This took place weekly for a total of 4 weeks. Reinforcement occurred in the daily huddles, staff meetings, and weekly newsletter. At the conclusion of the 4 weeks, another ProQOL survey was conducted to evaluate the effect of the intervention on $\mathrm{CF}$ and $\mathrm{CS}$.

\section{Refreezing}

Refreezing is to symbolize the act of reinforcing, stabilizing, and solidifying the new change after the second phase (Burnes, 2004). According to Lewin's Change Model, this is the phase where the change takes place as the new normal to ensure that changes are permanent (Manchester et al., 2014). This phase will be sustained by the clinical nurse specialist and the nurse champions, who are passionate about improving nurses' wellbeing and CS, to ensure the continuity of the intervention after the implementation of the project. The CF program will be part of the new unit orientation and unit policy, and it will also be part of the annual competency.

A project timeline was important to stay on track and achieve the goals of the EBP project in a timely manner. The dates, tasks, and assigned team members are illustrated in the project timeline (see Appendix G). Although the cost of this project was minimal, it will save the organization more in the long run as replacing one nurse may cost 6 to 9 months' worth of the nurse's salary (Michael et al., 2019). See Table 1 for the project budget.

\section{Results}

The participants in this EBP project were the nurses who worked in the obstetrical unit who were 18 years of age and older. Since this DNP scholarly project poses a minimal risk to the 
participants, the IRB approved it as exempt (Johns Hopkins Medicine, n.d.). The project manager obtained permission to utilize the ProQOL tool (see Appendix H). Participants filled out the ProQOL survey pre and post intervention (see Appendix I). Participants were prescribed the intervention in the weekly newsletter and daily huddles. The nurse champions were instrumental to ensuring maximum contribution of the participants. The project manager obtained weekly mindfulness videos from a certified health coach to be offered to the staff (see Appendices J and K). All data were kept and transferred to the same SharePoint drive that is secured and includes limited access between only the DNP student and the DNP preceptor (see Appendix L).

Statistical analysis was conducted using the IntellectusStatistics software. Participant demographics including age group categories, day or night shift, education degree, and years of nursing experience and were described using frequency distribution and represented as a percentage. Frequencies and percentages are presented in Table 2. The ProQOL is a 30 -item selfreport questionnaire with three subscales. The first subscale assesses CS, which is defined as the joy received from being able to execute one's job properly. Higher scores on this scale indicate more satisfaction with one's capacity to care for others effectively. BO, or emotions of hopelessness and difficulty dealing with work or doing one's job efficiently, is measured on the second subscale. The third subscale assesses secondary traumatic stress (STS), which is defined as work-related secondary exposure to people who have been exposed to severely or traumatically stressful events. $\mathrm{BO}$ and $\mathrm{CF}$ are associated with higher scores on these subscales. On a 5 -item Likert scale (from 1 = "never" to $5=$ "very often"), participants were asked to rate how frequently each item was experienced in the past 30 days. Summing the item responses for each 10-item subscale is required for scoring. 
The total compassion satisfaction score was found by adding up the sum of the following questions: $3,6,12,16,18,20,22,24,27$, and 30. For the BO calculation, ProQOL guidelines reversed the score of the following questions: 1, 4, 15, 17, and 29 as the measure works better when these questions are asked in a positive way although they can tell us more when in their negative form. The total BO score was formed by adding the individual scores of the following questions: $1,4,8,10,15,17,19,21,26$, and 29 . The total STS score was formed by adding the individual scores of the following questions: $2,5,7,9,11,13,14,23,25$, and 28 . If each of these 3 categories scored 22 or less it was classified as low, while between 23 and 41 was classified as moderate, and 42 or more was classified as high. Based on these classifications, the results displayed a mean shift from a pretest classification of moderate to a posttest classification of high in CS and a mean shift from a pretest classification of moderate to a posttest classification low for both BO and STS.

The cross-tabulation variable for the demographic variables was the testing period that split the demographics for pre and posttest. The next step was to determine whether there was a statistically significant difference in the CS, BO, and STS scores between the pre and post testing periods. A two-tailed independent samples $t$-test was conducted to examine whether the mean of CS was significantly different between the pretest and posttest categories of the testing period. This was done using three independent samples t-tests where each of the testing constructs was the dependent variable and the testing period was the independent variable. The results of each of these tests are shown in Tables 3,4, and 5. The t-tests showed that there was a statistically significant difference in the CS, BO, STS scores between testing periods based on a p-value of less than or equal to 0.05 ; more specifically, the p-value for all three t-tests was less than 0.001 . 
The Pearson Correlation Coefficient Test was conducted to determine the correlation between CS, BO, and STS (see Table 6). Table 6 shows a strong negative relationship between CS and BO, a moderate negative relationship between CS and STS, and a fairly strong positive relationship between $\mathrm{BO}$ and STS.

Outcome measures included the percent of nurses who experienced CF and CS in the obstetrical unit before and after the implementation of this project. Additionally, secondary traumatic stress and burnout was assessed pre and post intervention based on the ProQOL survey. As a result of the mindfulness program, there was a $15.6 \%$ increase in the mean of the CS score from pretest to posttest, a $35.1 \%$ decrease in the mean of the BO score from pretest to posttest, and a $39.5 \%$ decrease in the mean of the STS score from pretest to posttest, as shown by the two-tailed independent samples t-tests.

Process measures included the percentage of nurses who completed the mindfulness program and the percentage of nurses who completed the ProQOL survey pre and post intervention. Balance measures for the 6-week EBP project did not cause any strain on the budget of the obstetrical unit because the intervention took place during the nurses' breaks and/or huddles. In the future, financial measures will include the total cost saved by the organization due to decreased nurse turnover rate as a result of an increased incidence of CS.

\section{Impact}

The project achieved both statistically and clinically significant results. Descriptive statistics indicated demographically that nurses between the ages of 26 and 54 were more likely to experience $\mathrm{CF}$. The results indicate that most nurses, regardless of their age, nursing degree, and years of nursing experience benefit from mindfulness as an intervention to increase CS and 
reduce $\mathrm{BO}$ and STS. A statistically significant improvement was noted in CS and a reduction in BO and STS.

The project addressed an important problem in nurses experiencing $\mathrm{CF}$ including $\mathrm{BO}$ and STS especially during the COVID 19 pandemic. Mindfulness as an intervention increased CS by $15.6 \%$ and reduced CF by $39.5 \%$. The COVID 19 pandemic caused limitations, including a limited number of participants, a low response rate for the pretest, and making this project virtual instead of face to face. Another limitation was that a paired t-test could not be performed on the ProQOL survey data to keep anonymity of participants. The nurse champions and stakeholders, under the guidance of the unit manager, will continue to offer awareness and intervention in practicing mindfulness. The mindfulness program will also be available for new hires and as a part of the nurses' annual competencies.

The project needed to be extended over a period of three months with multiple ProQOL surveys to further assess the impact of the program on reducing CF. Despite the above limitations, the results of this EBP project showed a statistically significant reduction in CF and an increase in CS, which warrants this program to be a part of initial nursing orientation, annual assessments, and widespread participation throughout the organization. The mindfulness program and protocol should be frequently evaluated to ensure sustainability of the EBP project.

\section{Dissemination Plan}

The first step to ensuring the dissemination was to share the outcome with the stakeholders, the team members, and the institution (Agency for Healthcare Research and Quality (AHRQ), 2014). Beyond raising awareness of CF, the goal is to engage hospital staff in the main intervention, as well as to promote the application of the CF policy (see Appendix M) to reduce $\mathrm{CF}$ and increase CS. The next step was to place flyers and develop newsletters to create 
the appropriate awareness about the project (AHRQ, 2014). Increased awareness will come through participants attending an introduction on the topic of CF and CS, which will be available virtually due to the COVID-19 pandemic (see Appendix N).

The DNP student shared the EBP project and outcomes with the nursing director, clinical nursing leaders, and unit staff. The distribution of the results of the DNP project will be included in the weekly newsletter email from the clinical nurse specialist and the DNP student. Another means for local and regional dissemination is to send emails and use websites and blogs to share the EBP project and increase awareness of the problem and the solution. The DNP student will share the EBP project goal and outcomes to the local and regional Virginia Council of Nurse Practitioner, the Virginia Nurses Association, and the Virginia Association of Doctors of Nursing Practice.

The DNP student is planning to publish the EBP project as an article in the Journal of Holistic Nursing. This journal is a peer-reviewed journal that promotes holism, wellness practice, and it is part of the Committee on Publication Ethics (2020) that is committed to transform and sustain the culture of publishing to ethical practice . On the journal's website, there is an author guide under the submission guidelines tab that offers great detail about specific guidelines in manuscript submission and time for review, decision, and production (Journal of Holistic Nursing, 2020).

\section{Conclusion}

The EBP project's aim was to implement a mindfulness program policy and protocol for the organization leaders to provide an intervention to the nursing staff to reduce $\mathrm{CF}$ and increase CS. The policy and protocol, data collection, data tracking, increased staff awareness, and pre and post ProQOL were developed and implemented. The intervention included an increased 
awareness of CF and mindfulness. CF is a global, national, and regional problem that affects nurses and healthcare providers. CF has an impact on decreased staff retention, increased workrelated mistakes, decreased employee satisfaction, and decreased patient safety (Adimando, 2018; Durkin et al., 2016; Klein et al., 2018; Michael et al., 2019). The JHNEBP and Lewin's Change Model guided the intervention and created the protocol and policy to improve the participants' quality of life by reducing CF and increasing CS. A thorough literature review was conducted. Based on the literature review, the intervention was implemented to create a policy that provides the nursing staff with a protocol to reduce $\mathrm{CF}$ and increase $\mathrm{CS}$. 


\section{References}

Adimando A. (2018). Preventing and alleviating compassion fatigue through self-care: An educational workshop for nurses. Journal of Holistic Nursing: Official Journal of the American Holistic Nurses' Association, 36(4), 304-317. https://doiorg.proxy.library.vcu.edu/10.1177/0898010117721581

Agency for Healthcare Research and Quality (2012). Assessing organizational readiness: SWOT analysis.

https://www.ahrq.gov/teamstepps/instructor/reference/swotnalysis.html

Agency for Healthcare Research and Quality (2014). Quick-start guide to dissemination for practice-based research networks.

https://pbrn.ahrq.gov/sites/default/files/AHRQ\%20PBRN\%20Dissemination\%20QuickSt art\%20Guide 0.pdf

American Psychological Association (2015). The road to resilience. http://www.apa.org/helpcenter/road-resilience.aspx.

Berger, J., Polivka, B., Smoot, E. A., \& Owens, H. (2015). Compassion fatigue in pediatric nurses. Journal of Pediatric Nursing, 30(6), e11-e17. https://doi.org/10.1016/j.pedn.2015.02.005

Blackburn, L. M., Thompson, K., Frankenfield, R., Harding, A., \& Lindsey, A. (2020). The THRIVEC Program: Building oncology nurse resilience through self-care strategies. Oncology Nursing Forum, 47(1), E25-E34. https://doi.org/10.1188/20.ONF.E25-E34

Burnes, B. (2004). Kurt Lewin and the planned approach to change: A re-appraisal. Journal of 
Management Studies, 41 (6), 977-1002. https://doi.org/10.1111/j.1467$\underline{6486.2004 .00463 . x}$

Centers for disease Control and Prevention (n.d.). Writing smart objectives. https://www.cdc.gov/dhdsp/evaluation_resources/guides/writing-smart-objectives.htm

Cimiotti, J. P., Aiken, L. H., Sloane, D. M., \& Wu, E. S. (2012). Nurse staffing, burnout, and health care-associated infection. American Journal of Infection Control, 40(6), 486-490. https://doi.org/10.1016/j.ajic.2012.02.029

Cocker, F., \& Joss, N. (2016). Compassion fatigue among healthcare, emergency and community service workers: A systematic review. International Journal of Environmental Research and Public Health, 13(6), 618-636. https://doi.org/10.3390/ijerph13060618

Committee on Publication Ethics (2020). About COPE. https://publicationethics.org/about/ourorganisation

Craigie, M., Slatyer, S., Hegney, D., Osseiran-Moisson, R., Gentry, E., Davis, S., Dolan, T., Rees, C. (2016). A pilot evaluation of a mindful self-care and resiliency (MSCR) intervention for nurses. Mindfulness, 7, 764-774. https://doi.org/10.1007/s12671-0160516-X

Dearholt, S. L. \& Dang, D. (2012). Johns Hopkins nursing evidence-based practice: Model and guidelines, (2nd ed.) Sigma Theta Tau International, 1-264. https://books.google.com/books?hl=en\&lr=\&id=W3OTUMuaAoC\&oi=fnd\&pg=PT24 $\underline{\& d q}=$ johns + hopkins + evidence + based + practice + model $\&$ ots $=0$ TEQWeqezI\&sig $=$ ZQJ8R $\underline{\text { LGaqejeEolLDR7wcJiy9P4\#v= }=\text { enepage \&q }=\text { johns } \% 20 \text { hopkins } \% 20 \text { evidence } \% 20 \text { based } \% 2}$ 0practice $\% 20$ model $\& \mathrm{f}=$ false

Dreher, M. M., Hughes, R. G., Handley, P. A., \& Tavakoli, A. S. (2019). Improving retention 
among certified nursing assistants through compassion fatigue awareness and self-care skills education. Journal of Holistic Nursing: Official Journal of the American Holistic Nurses' Association, 37(3), 296-308. https://doi.org/10.1177/0898010119834180

Duhoux, A., Menear, M., Charron, M., Lavoie-Tremblay, M., \& Alderson, M. (2017). Interventions to promote or improve the mental health of primary care nurses: A systematic review. Journal of Nursing Management, 25(8), 597-607. https://doi.org/10.1111/jonm.12511

Durkin, M., Beaumont, E., Martin, C. J. H., \& Carson, J. (2016). A pilot study exploring the relationship between self-compassion, self-judgement, self-kindness, compassion, professional quality of life and wellbeing among UK community nurses. Nurse Education Today, 46, 109-114. https://doi-org.proxy.library.vcu.edu/10.1016/j.nedt.2016.08.030

Figley, C.R. (1995). Compassion fatigue: Coping with secondary traumatic stress disorder in those who treat the traumatized. Brunner/Mazel.

Figley, C.R., \& Stamm, B.H. (1996). Psychometric review of compassion fatigue self-test. The Sidran Press.

Fowler, M.D.M. (2018). Code of ethics for nurses with interpretive statements: Development, interpretation, and application. American Nurses Association.

Gentry, J.E. (2002). Compassion fatigue: A crucible of transformation. Journal of Trauma Practice, 1 (3), 37-61. https://doi.org/10.1300/J189v01n03 03

Graystone, R. (2019). Prevent compassion fatigue and burnout with a magnet culture. The Journal of Nursing Administration, 49 (5), 231-233. https://doi.org/10.1097/NNA.0000000000000743 
Harris, C., \& Quinn Griffin, M. T. (2015). Nursing on empty: Compassion fatigue, signs, symptoms, and system interventions. Journal of Christian Nursing, 32(2), 80-87. https://doi.org/10.1097/CNJ.0000000000000155

Hart, P. L., Brannan, J. D., \& De, C. M. (2014). Resilience in nurses: An integrative review. Journal of Nursing Management, 22(6), 720-734. https://doi.org.proxy.library.vcu.edu/10.1111/j.1365-2834.2012.01485.x

Hegney, D. G., Rees, C. S., Eley, R., Osseiran-Moisson, R., \& Francis, K. (2015). The contribution of individual psychological resilience in determining the professional quality of life of Australian nurses. Frontiers of Psychology, 21(6), 1-8. https://doi.org/10.3389/fpsyg.2015.01613

Hooper, C., Craig, J., Janvrin, D. R., Wetsel, M. A., \& Reimels, E. (2010). Compassion satisfaction, burnout, and compassion fatigue among emergency nurses compared with nurses in other selected inpatient specialties. Journal of Emergency Nursing, 36(5), 420427. https://doi.org/10.1016/j.jen.2009.11.027

Hunsaker, S., Chen, H. C., Maughan, D., \& Heaston, S. (2015). Factors that influence the development of compassion fatigue, burnout, and compassion satisfaction in emergency department nurses. Journal of Nursing Scholarship: An official publication of Sigma Theta Tau International Honor Society of Nursing, 47(2), 186-194. https://doi.org/10.1111/jnu.12122

Jakel, P., Kenney, J., Ludan, N., Miller, P. S., McNair, N., \& Matesic, E. (2016). Effects of the use of the provider resilience mobile application in reducing compassion fatigue in oncology nursing. Clinical Journal of Oncology Nursing, 20(6), 611-616. https://doi.org/10.1188/16.CJON.611-616 
Jarrad, R., Hammad, S., Shawashi, \& Mahmoud, N. (2018). Compassion fatigue and substance use among nurses. Annal of General Psychiatry, 17(13), 1-8. https://doi.org/10.1186/s12991-018-0183-5

Johns Hopkins Medicine (n.d.). Center for evidence-based practice. https://www.hopkinsmedicine.org/evidence-based-practice/ijhn_2017_ebp.html

Joinson C. (1992). Coping with compassion fatigue. Nursing, 22(4), 116-120.

Journal of Holistic Nursing (2020). Submission guidelines. https://us.sagepub.com/en$\underline{\text { us/nam/journal/journal-holistic-nursing\#submission-guidelines }}$

Kabat-Zinn, J. (2003). Mindfulness-based interventions in context: Past, present, and future. Clinical Psychology: Science and Practice,10(2), 144-156. https://doi.org/10.1093/clipsy.bpg016.

Kelly, L., Runge, J., \& Spencer, C. (2015). Predictors of compassion fatigue and compassion satisfaction in acute care nurses. Journal of Nursing Scholarship: An Official Publication of Sigma Theta Tau International Honor Society of Nursing, 47(6), 522-528. https://doi.org/10.1111/jnu.12162

Kelly, L., \& Todd, M. (2017). Compassion fatigue and the healthy work environment. $A A C N$ Advanced Critical Care, 28(4), 351-358. https://doi.org/10.4037/aacnacc2017283

Klein, C. J., Riggenbach-Hays, J. J., Sollenberger, L. M., Harney, D. M., \& McGarvey, J. S. (2018). Quality of life and compassion satisfaction in clinicians: A pilot intervention study for reducing compassion fatigue. The American Journal of Hospice \& Palliative Care, 35(6), 882-888. https://doi-org.proxy.library.vcu.edu/10.1177/1049909117740848

Lehto, R. H., Heeter, C., Allbritton, M., \& Wiseman, M. (2018). Hospice and palliative care 
provider experiences with meditation using mobile applications. Oncology Nursing Forum, 45(3), 380-388. https://doi.org/10.1188/18.ONF.380-388

Manchester, J., Gray-Miceli, D. L., Metcalf, J. A., Paolini, C. A., Napier, A. H., Coogle, C. L., \& Owens, M. G. (2014). Facilitating Lewin's change model with collaborative evaluation in promoting evidence-based practices of health professionals. Evaluation and Program Planning, 47, 82-90. https://doi.org/10.1016/j.evalprogplan.2014.08.007

McGarr, D., Cashin, A., \& Fowler, C. (2012). Child and adolescent psychiatric nursing and the "plastic man": Reflections on the implementation of change drawing insights from Lewin's theory of planned change. Contemporary Nurse: A Journal for the Australian Nursing Profession, 41(2), 263-270. https://doi.org/10.5172/conu.2012.41.2.263

Michael, S., Villarreal, P.M., Ferguson, M. F., Willer, J. L., Zane, R. D., Flarity, K. (2019). Virtual reality-based resilience program. Clinical Journal of Oncology Nursing, 23 (6). 664-667. https://doi.org/10.1188/19.CJON.664-667

Milligan, F., \& Almomani, E. (2020). Death anxiety and compassion fatigue in critical care nurses. British Journal of Nursing, 29(15), 874-879. https://doi.org/10.12968/bjon.2020.29.15.874

Mooney, C., Fetter, K., Gross, B. W., Rinehart, C., Lynch, C., \& Rogers, F. B. (2017). A preliminary analysis of compassion satisfaction and compassion fatigue with considerations for nursing unit specialization and demographic factors. Journal of Trauma Nursing: The Official Journal of the Society of Trauma Nurses, 24(3), 158-163. https://doi.org/10.1097/JTN.0000000000000284 
Mulholand, B. (2017, July 24). 8 critical change management models to evolve and survive. Process Street. https://www.process.st/change-management-models/\#Lewin's-changemanagement-model.

Nolte, A. G. W., Downing, C., Temane, A., \& Hastings-Tolsma, M. (2017). Compassion fatigue in nurses: A metasynthesis. Journal of Clinical Nursing, 26, 4364- 4378. https://doi-org.proxy.library.vcu.edu/10.1111/jocn.13766

NSI Nursing Solutions (2020). 2020 NSW national health care retention \& RN staffing report. https://www.nsinursingsolutions.com/Documents/Library/NSI_National_Health_Care_R etention_Report.pdf

Ortega-Campos, E., Vargas-Roman, K., Velando-Soriano, A., Suleiman-Martos, N., Canadas -de la Fuente, G. A., Albendin-Garcia, L. \& Gomez-Urquiza, J. L. (2020). Compassion fatigue, compassion satisfaction, and burnout in oncology nurses: A systematic review and metaanalysis. Sustainability, 12 (72). 1-12. https://doi.org/10.3390/su12010072

Perregrini, M. (2019). Combating compassion fatigue. Nursing, 49 (2), 50-54. https://doi.org.10.1097/01.NURSE.0000552704.58125.fa

Polat, H., Turan, G. B., \& Tan, M. (2020). Determination of the relationship of the spiritual orientation of nurses with compassion fatigue, burnout, and compassion satisfaction. Perspectives in Psychiatric Care, 10.1111/ppc.12513, 1-6. https://doi.org/10.1111/ppc.12513

PRISMA (n.d.). Prisma 2009 flow diagram. http://www.prismastatement.org/documents/PRISMA\%202009\%20flow\%20diagram.doc

Rajeswari, H., Sreelekha, B. K., Nappinai, S., Subrahmanyam, U., \& Rajeswari, V. (2020). Impact of accelerated recovery program on compassion fatigue among nurses in South 
India. Iranian Journal of Nursing and Midwifery Research, 25(3), 249-253. https://doi.org/10.4103/ijnmr.IJNMR_218_19

Rushton, C. H., Batcheller, J., Schroeder, K., \& Donohue, P. (2015). Burnout and resilience among nurses practicing in high-intensity settings. American Journal of Critical-Care Nurses, 24(5), 412-420. https://doi.org/10.4037/ajcc2015291

Rutherford, M. (2018, April 17). ICH E6 (R2) and data integrity: Four key principles. Association of Clinical Research Professionals. https://acrpnet.org/2018/04/17/ich-e6r2-data-integrity-four-key-principles/

Sacco, T. L., Ciurzynski, S. M., Harvey, M. E., \& Ingersoll, G. L. (2015). Compassion satisfaction and compassion fatigue among critical care nurses. Critical Care Nurse, 35(4), 32-43. https://doi-org.proxy.library.vcu.edu/10.4037/ccn2015392

Sinclair, S., Raffin-Bouchal, S., Venturato, L., Mijovic-Kondejewski, J., Smith-MaDonald, L. (2017). Compassion fatigue: A meta-narrative review of the healthcare literature. International Journal of Nursing Studies, 69, 9-24. https://doi.org/10.1016/j.ijnurstu.2017.01.003

Slatyer, S., Craigie, M., Heritage, B., Davis, S., \& Rees, C. (2018). Evaluating the effectiveness of a brief mindful self-care and resiliency (MSCR) intervention for nurses: A controlled trial. Mindfulness, 9(2), 534-546. https://doi.org/10.1007/s12671-017-0795-x

Social Work Foot Prints (2017, October 30). Kurt Lewin - Father of modern social psychology. https://www.socialworkfootprints.org/english-articles/kurt-lewin-father-of-modern$\underline{\text { social-psychology?store-page }=\text { signIn\&returnUrl=?store-page } \% 3 \text { DCompetency- }}$ Mapping-p231259759

Stamm, B.H. (1999). Secondary traumatic stress: Self-care issue for clinicians, researchers, 
and educators (2nd ed.). The Sidran Press.

Stamm, B.H. (2010). Professional quality of life measure. ProQOL. https://www.proqol.org/ProQol_Test.html

Substance Abuse and Mental Health Services Administration (n.d.). Tips for healthcare professionals: Coping with stress and compassion fatigue. https://store.samhsa.gov/sites/default/files/SAMHSA_Digital_Download/PEP20-01-01016 508.pdf

Sullivan, C. E., King, A. R., Holdiness, J., Durrell, J., Roberts, K. K., Spencer, C., Roberts, J., Ogg, S. W., Moreland, M. W., Browne, E. K., Cartwright, C., Crabtree, V. M., Baker, J. N., Brown, M., Sykes, A., \& Mandrell, B. N. (2019). Reducing compassion fatigue in inpatient pediatric oncology nurses. Oncology Nursing Forum, 46(3), 338-347. https://doi-org.proxy.library.vcu.edu/10.1188/19.ONF.338-347

Welp, A., Meier, L. L., \& Manser, T. (2015). Emotional exhaustion and workload predict clinician-rated and objective patient safety. Frontiers in Psychology, 5, 1573. 1-13. https://doi.org/10.3389/fpsyg.2014.01573

Wentzel, D., \& Brysiewicz, P. (2017). Integrative review of facility interventions to manage compassion fatigue in oncology nurses. Oncology nursing forum, 44(3), E124-E140. https://doi.org/10.1188/17.ONF.E124-E140

White, K. M., Dudley-Brown, S. \& Terhaar, M. F. (Eds.). (2016). Translation of evidence into nursing and health care (2nd ed.). Springer Publishing Company.

Wojciechowski, E., Pearsall, T., Murphy, P., \& French, E. (2016). A case review: Integrating Lewin's theory with Lean's system approach for change. Online Journal of Issues in Nursing, 21(2), 4. https://doi-org.proxy.library.vcu.edu/10.3912/OJIN.Vol21No02Man04 
Wu, S., Singh-Carlson, S., Odell, A., Reynolds, G., \& Su, Y. (2016). Compassion fatigue, burnout, and compassion satisfaction among oncology nurses in the United States and Canada. Oncology Nursing forum, 43(4), E161-E169. https://doi.org/10.1188/16.ONF.E161-E169

Xu, H. , Kynoch, K., Tuckett, A., Eley, R. (2020). Effectiveness of interventions to reduce emergency department staff occupational stress and/or burnout: A systematic review. JBI Evidence Synthesis, 18 (6), 1156-1188.

https://doi: 10.11124/JBISRIR-D-19-00252

Y1lmaz, G., Üstün, B., \& Günüşen, N. P. (2018). Effect of a nurse-led intervention programme on professional quality of life and post-traumatic growth in oncology nurses. International Journal of Nursing Practice, 24(6), e12687. https://doi.org/10.1111/ijn.12687

Zajac, L. M., Moran, K. J., \& Groh, C. J. (2017). Confronting compassion fatigue: Assessment and intervention in inpatient oncology. Clinical Journal of Oncology Nursing, 21(4), 446-453. https://doi-org.proxy.library.vcu.edu/10.1188/17.CJON.446-453 
Table 1

Budget

\begin{tabular}{|l|r|l|l|}
\hline EXPENSES & & REVENUE & \\
\hline Direct & & Billing & \\
\hline Salary and benefits & None & Grants & \\
\hline Supplies & $\$ 200.00$ & Institutional budget support & \\
\hline Services & None & & \\
\hline Statistician & $\$ 99.00$ & & \\
\hline & & & \\
\hline Indirect & & & \\
\hline Overhead & & & \\
\hline \multicolumn{2}{|l|}{} & & \\
\hline Total Expenses & & & \\
\hline Net Balance & $\$ 299.00$ & Total Revenue & \\
\hline
\end{tabular}




\section{Table 2}

Frequency Table for Demographic Variables

\begin{tabular}{|c|c|c|}
\hline Variable & Pretest & Posttest \\
\hline \multicolumn{3}{|l|}{ Age } \\
\hline $18-25$ & $1(4 \%)$ & $2(8 \%)$ \\
\hline $26-34$ & $8(32 \%)$ & $8(32 \%)$ \\
\hline $35-44$ & $8(32 \%)$ & $5(20 \%)$ \\
\hline $45-54$ & $5(20 \%)$ & $8(32 \%)$ \\
\hline $55-64$ & $3(12 \%)$ & $2(8 \%)$ \\
\hline Missing & $0(0 \%)$ & $0(0 \%)$ \\
\hline \multicolumn{3}{|l|}{ Degree } \\
\hline Associate degree & $1(4 \%)$ & $3(12 \%)$ \\
\hline Bachelor's degree & $20(80 \%)$ & $19(76 \%)$ \\
\hline Master's degree & $1(4 \%)$ & $2(8 \%)$ \\
\hline Post-master's certificate & $2(8 \%)$ & $1(4 \%)$ \\
\hline Missing & $1(4 \%)$ & $0(0 \%)$ \\
\hline \multicolumn{3}{|l|}{ Years of Nursing Experience } \\
\hline $1-3$ & $1(4 \%)$ & $5(20 \%)$ \\
\hline $4-7$ & $5(20 \%)$ & $3(12 \%)$ \\
\hline $8-12$ & $7(28 \%)$ & $8(32 \%)$ \\
\hline $13-15$ & $3(12 \%)$ & $2(8 \%)$ \\
\hline Above 15 & $9(36 \%)$ & $7(28 \%)$ \\
\hline
\end{tabular}


Missing

$$
0(0 \%) \quad 0(0 \%)
$$

Years of Experience in Current Position

1-3

4-7

8-12

13-15

Above 15

Missing

Shift

Day

Night

Missing

Part time/Full time

Full-time

Part-time

Missing

$16(64 \%) \quad 14(56 \%)$

$9(36 \%) \quad 11(44 \%)$

$0(0 \%) \quad 0(0 \%)$

$23(92 \%) \quad 21(84 \%)$

$2(8 \%) \quad 4(16 \%)$

$0(0 \%) \quad 0(0 \%)$ 
Table 3

Two-Tailed Independent Samples t-Test for Compassion Satisfaction by Testing Period

\begin{tabular}{|c|c|c|c|c|c|c|c|}
\hline \multirow[b]{2}{*}{ Variable } & \multicolumn{2}{|c|}{ Pretest } & \multicolumn{2}{|c|}{ Posttest } & \multirow[b]{2}{*}{$t$} & \multirow[b]{2}{*}{$p$} & \multirow[b]{2}{*}{$d$} \\
\hline & $M$ & $S D$ & $M$ & $S D$ & & & \\
\hline Compassion Satisfaction & 39.42 & 5.57 & 45.57 & 4.02 & -4.32 & $<.001$ & 1.27 \\
\hline
\end{tabular}

Note. $\mathrm{N}=47$. Degrees of Freedom for the $t$-statistic $=45 . d$ represents Cohen's $d$. 
Table 4

Two-Tailed Independent Samples t-Test for Burnout by Testing Period

\begin{tabular}{|c|c|c|c|c|c|c|c|}
\hline \multirow[b]{2}{*}{ Variable } & \multicolumn{2}{|c|}{ Pretest } & \multicolumn{2}{|c|}{ Posttest } & \multirow[b]{2}{*}{$t$} & \multirow[b]{2}{*}{$p$} & \multirow[b]{2}{*}{$d$} \\
\hline & $M$ & $S D$ & $M$ & $S D$ & & & \\
\hline Burnout & 24.20 & 5.12 & 15.70 & 5.30 & 5.65 & $<.001$ & 1.63 \\
\hline
\end{tabular}

Note. $\mathrm{N}=48$. Degrees of Freedom for the $t$-statistic $=46 . d$ represents Cohen's $d$. 
Table 5

Two-Tailed Independent Samples t-Test for Secondary Traumatic Stress by Testing Period

\begin{tabular}{cccccccccc}
\hline & \multicolumn{3}{c}{ Pretest } & \multicolumn{3}{c}{ Posttest } & & & \\
Variable & $M$ & $S D$ & $M$ & $S D$ & & & & \\
\cline { 2 - 6 } & & & & & & & & $d$ \\
\hline Secondary Traumatic Stress & 25.10 & 5.96 & 15.19 & 3.44 & 6.60 & $<.001$ & 2.04
\end{tabular}

Note. $\mathrm{N}=42$. Degrees of Freedom for the $t$-statistic $=40 . d$ represents Cohen's $d$. 
Table 6

Pearson Correlation Results Among Compassion Satisfaction, Burnout, and Secondary Traumatic Stress

\begin{tabular}{|c|c|c|c|}
\hline Combination & $r_{\mathrm{p}}$ & $95 \% \mathrm{CI}$ & $p$ \\
\hline Compassion Satisfaction-Burnout & -0.82 & {$[-0.90,-0.68]$} & $<.001$ \\
\hline Compassion Satisfaction-Secondary Traumatic Stress & -0.61 & {$[-0.78,-0.37]$} & $<.001$ \\
\hline Burnout-Secondary Traumatic Stress & 0.76 & {$[0.59,0.87]$} & $<.001$ \\
\hline
\end{tabular}

Note. $n=39$. 


\section{Figure 1}

Records identified through database searching: CINAHL, PubMed, Ovid, and PsycINFO

$(\mathrm{n}=537)$
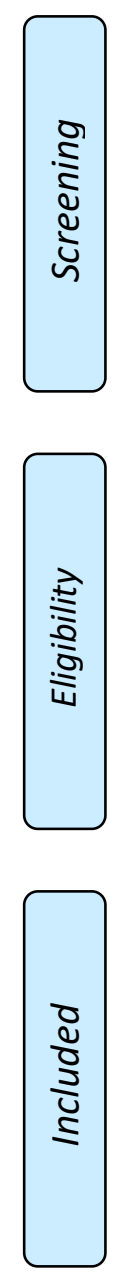

Additional records identified through other sources none
Records excluded as they are only focused on the prevalence of $\mathrm{CF}$, CF risk factors, or nonhealthcare professionals $(\mathrm{n}=300)$

Full-text articles excluded as they did not focus on $\mathrm{CF}$, did not evaluate the effectiveness of a $\mathrm{CF}$ prevention or

Studies included in quantitative synthesis (meta-analysis)

$$
(n=14)
$$

$\longrightarrow \begin{gathered}\text { Full-text articles } \\ \text { excluded as they did not } \\ \text { focus on CF, did not } \\ \text { evaluate the } \\ \text { effectiveness of a CF } \\ \text { prevention or } \\ \text { intervention program, or } \\ \text { did not utilize a specific } \\ \text { validated measure of } \\ \text { CF. } \\ (\mathrm{n}=183)\end{gathered}$


Note. Adapted from "Preferred Reporting Items for Systematic Reviews and Meta-Analyses: The PRISMA Statement," by Moher D, Liberati A, Tetzlaff J, Altman DG, The PRISMA Group, 2009, PloS Med 6(7): e1000097 (https://doi.org/10.1371/journal.pmed1000097). Copyright 2009 by Creative Commons Attribution Non-Commercial License. 
Appendix A

\section{Evidence-Based Table}

\begin{tabular}{|c|c|c|c|c|c|c|}
\hline Citation & $\begin{array}{c}\text { Design, } \\
\text { Level } \\
\text { Quality } \\
\text { Grade }\end{array}$ & $\begin{array}{c}\text { Sample } \\
\text { Sample size }\end{array}$ & $\begin{array}{c}\text { Intervention } \\
\text { Comparison } \\
\text { (Definitions should } \\
\text { include any specific } \\
\text { research tools used } \\
\text { along with reliability } \\
\& \text { validity) }\end{array}$ & $\begin{array}{l}\text { Theoretical } \\
\text { Foundation }\end{array}$ & $\begin{array}{l}\text { Outcome } \\
\text { Definition }\end{array}$ & $\begin{array}{c}\text { Usefulness } \\
\text { Results } \\
\text { Key Findings }\end{array}$ \\
\hline $\begin{array}{l}\text { Adimando A. } \\
\text { (2018). } \\
\text { Preventing and } \\
\text { alleviating } \\
\text { compassion } \\
\text { fatigue through } \\
\text { self-care: An } \\
\text { educational } \\
\text { workshop for } \\
\text { nurses. Journal } \\
\text { of Holistic } \\
\text { Nursing: } \\
\text { Official Journal } \\
\text { of the American } \\
\text { Holistic Nurses' } \\
\text { Association, } 36( \\
\text { 4), } 304-317 . \\
\text { https://doi- } \\
\text { org.proxy.librar } \\
\text { y.vcu.edu/10.11 } \\
77 / 0898010117 \\
721581\end{array}$ & $\begin{array}{c}\text { Training } \\
\text { workshop for } \\
\text { Nurses } \\
\text { Level V } \\
\text { Grade A } \\
\text { Evidence } \\
\text { based project }\end{array}$ & $\begin{array}{l}24 \text { nurses } \\
\text { participated in } \\
\text { the training } \\
\text { workshop }\end{array}$ & $\begin{array}{l}\text {-Increase awareness of } \\
\text { risk factors, causes of, and } \\
\text { symptoms of compassion } \\
\text { fatigue (CF) to empower } \\
\text { nurses to identify and } \\
\text { prevent its onset. } \\
\text {-Provide nurses with } \\
\text { demonstrations and } \\
\text { recommendations of self- } \\
\text { care activities to reduce } \\
\text { and prevent CF. } \\
\text {-The above objectives } \\
\text { were accomplished } \\
\text { through a training } \\
\text { workshop for nurses. } \\
\text {-Workshop was about one } \\
\text { hour. } \\
\text {-During the workshop, the } \\
\text { nurses were provided with } \\
\text { various self-care and stress } \\
\text { management activities and } \\
\text { techniques to reduce CF. } \\
\text { Activities included: } \\
\text { breathing techniques, } \\
\text { using or smelling essential } \\
\text { oils, taking breaks outside } \\
\text { of the unit for meals or } \\
\text { walking meditations, and }\end{array}$ & None & $\begin{array}{l}\text { Demographic surveys } \\
\text { collected: out of } 24 \\
\text { nurses, only } 22 \\
\text { answered the } \\
\text { demographic survey. } \\
\text { Quantitative data } \\
\text { obtained from } \\
\text { Professional Quality } \\
\text { of Life Scale (Pro } \\
\text { QOL): pre and post- } \\
\text { intervention tests and } \\
\text { compared via a } \\
\text { paired t test model. } \\
\text { Qualitative data } \\
\text { obtained from } \\
\text { compassion fatigue } \\
\text { knowledge test }\end{array}$ & $\begin{array}{l}\text { Quantitative data: there was a significant difference } \\
\text { between the pretest mean scores and the posttest } \\
\text { mean score. } \\
\text { Qualitative data: positive response to the } \\
\text { intervention, } 100 \% \text { of the participants were either } \\
\text { somewhat likely or likely to recommend attendance } \\
\text { of this workshop. } \\
\text { The majority of participants expressed satisfaction } \\
\text { with the workshop especially the relaxation and/or } \\
\text { stress-relieving exercises. } \\
\text { Limitations: } \\
\text {-Physical space, preferably should be away from the } \\
\text { unit } \\
\text { - Financial limitations: budget to allow nurses to } \\
\text { attend the workshop was not available, therefore } \\
\text { this training workshop was originally planned to be } \\
\text { four hours and was reduced to one hour due to } \\
\text { budget cut. } \\
\text {-Electronic limitations: due to organizational policy, } \\
\text { it was prohibited to contact employees via e-mail } \\
\text { for any research project. } \\
\text {-Ideally, } 2 \text { weeks post intervention was preferably } \\
\text { but due to the time limitation, it was not done. }\end{array}$ \\
\hline
\end{tabular}




\begin{tabular}{|c|c|c|c|c|c|c|}
\hline & & & $\begin{array}{l}\text { using certain herbs and } \\
\text { teas to promote relaxation. }\end{array}$ & & & \\
\hline $\begin{array}{l}\text { Blackburn, L. } \\
\text { M., Thompson, } \\
\text { K., } \\
\text { Frankenfield, } \\
\text { R., Harding, A., } \\
\text { \& Lindsey, A. } \\
\text { (2020). The } \\
\text { THRIVEC } \\
\text { Program: } \\
\text { Building } \\
\text { oncology nurse } \\
\text { rsilience } \\
\text { through self- } \\
\text { care } \\
\text { srategies. Oncol } \\
\text { ogy Nursing } \\
\text { Forum, 47(1), } \\
\text { E25-E34. } \\
\text { https://doi.org/1 } \\
\underline{0.1188 / 20 . O N F .} \\
\text { E25-E34 }\end{array}$ & $\begin{array}{c}\text { Evidence- } \\
\text { based program } \\
\text { Level V } \\
\text { Grade B }\end{array}$ & $\begin{array}{l}164 \text { oncology } \\
\text { staff, } 160 \text { were } \\
\text { nurses or } \\
\text { advance } \\
\text { practice RNs at } \\
\text { the James (The } \\
\text { James) Cancer } \\
\text { Hospital and } \\
\text { Richard J. } \\
\text { Solove } \\
\text { Research } \\
\text { Institute in } \\
\text { Columbus, } \\
\text { Ohio }\end{array}$ & $\begin{array}{l}\text { The THRIVE Program } \\
\text { was developed by two } \\
\text { clinical nurse specialists } \\
\text { one with certification in } \\
\text { psychiatry and mental } \\
\text { health. The program } \\
\text { consisted of an } 8 \text {-hour } \\
\text { retreat designed to teach } \\
\text { self-care strategies, } \\
\text { followed by a } 6 \text { week } \\
\text { private group study on a } \\
\text { social media platform, and } \\
\text { a final 2-hour wrap-up } \\
\text { session. The retreat } \\
\text { included different } \\
\text { sessions: mindfulness, art, } \\
\text { journaling, guided } \\
\text { imagery, and acupressure } \\
\text { and self-facial massage. }\end{array}$ & $\begin{array}{l}\text { Relationship- } \\
\text { based care } \\
\text { (RBC) is the } \\
\text { theoretical } \\
\text { framework } \\
\text { that supports } \\
\text { the } \\
\text { professional } \\
\text { practice model } \\
\text { for nursing at } \\
\text { The James. } \\
\text { RBC is an } \\
\text { evidence- } \\
\text { based model } \\
\text { that helps to } \\
\text { create a } \\
\text { healing } \\
\text { environment. } \\
\text { There are three } \\
\text { main } \\
\text { components } \\
\text { for the RBC: } \\
\text { relationships } \\
\text { with patients } \\
\text { and their } \\
\text { families, } \\
\text { relationships } \\
\text { with } \\
\text { colleagues, } \\
\text { and } \\
\text { relationship } \\
\text { with self. } \\
\text { Resilience is } \\
\text { based on self- } \\
\text { care. Effective } \\
\text { self-care is } \\
\text { based on the } \\
\text { individual } \\
\text { ability to } \\
\text { possess the } \\
\text { skills and } \\
\text { knowledge to }\end{array}$ & $\begin{array}{l}\text { The Compassion } \\
\text { Fatigue Short Scale } \\
\text { (CFSS) and the } \\
\text { Connor-Davidson } \\
\text { Resilience Scale } \\
\text { (CD-RISC) were } \\
\text { used to evaluate the } \\
\text { effects of THRIVE } \\
\text { program. All } \\
\text { participants } \\
\text { completed both tests } \\
\text { at the beginning and } \\
\text { at the completion of } \\
\text { the program. }\end{array}$ & $\begin{array}{l}\text { In self-assessment prior to THRIVE, nurse } \\
\text { managers demonstrated the greatest degree of } \\
\text { burnout, bedside nurses demonstrated the greatest } \\
\text { degree of secondary trauma. } \\
\text { The greatest improvement in average scores from } \\
\text { pre-to post-program assessment was in increased } \\
\text { resilience and decrease burnout. Increased } \\
\text { resilience scores were sustained for a six-month } \\
\text { period after THRIVE participation. } \\
\text { Implications: } \\
\text { Oncology healthcare providers must identify self- } \\
\text { care strategies that build their resilience for long, } \\
\text { successful careers. } \\
\text { Resilience programs can be effective way for } \\
\text { building staff resilience and decreasing staff } \\
\text { burnout and secondary trauma. } \\
\text { Oncology nurses can be leaders in this area if given } \\
\text { the opportunity to learn new skills, the support to } \\
\text { apply them over time, and the self-knowledge to } \\
\text { realize what a difference they make in long tern } \\
\text { career while treating patients with cancer. }\end{array}$ \\
\hline
\end{tabular}




\begin{tabular}{|c|c|c|c|c|c|c|}
\hline & & & & $\begin{array}{l}\text { manage his or } \\
\text { her own stress, } \\
\text { express } \\
\text { personal needs } \\
\text { and values, } \\
\text { and balance } \\
\text { the job } \\
\text { demands with } \\
\text { physical and } \\
\text { emotional } \\
\text { wellbeing. }\end{array}$ & & \\
\hline $\begin{array}{l}\text { Craigie, M., } \\
\text { Slatyer, S., } \\
\text { Hegney, D., } \\
\text { Osseiran- } \\
\text { Moisson, R., } \\
\text { Gentry, E., } \\
\text { Davis, S., } \\
\text { Dolan, T., Rees, } \\
\text { C. (2016). A } \\
\text { pilot evaluation } \\
\text { of a mindful } \\
\text { self-care and } \\
\text { resiliency } \\
\text { (MSCR) } \\
\text { intervention for } \\
\text { nurses. } \\
\text { Mindfulness, 7, } \\
\text { 764-774. } \\
\text { https://doi.org/1 } \\
0.1007 / s 12671- \\
016-0516-x\end{array}$ & $\begin{array}{c}\text { Pilot study } \\
\text { Level V } \\
\text { Grade B }\end{array}$ & $\begin{array}{l}21 \text { nurses } \\
\text { recruited from } \\
\text { a large } \\
\text { teaching } \\
\text { hospital in } \\
\text { Western } \\
\text { Australia who } \\
\text { participated in } \\
\text { a training } \\
\text { program called } \\
\text { mindful self- } \\
\text { care and } \\
\text { resiliency } \\
\text { (MSCR). } \\
\text { Exclusion } \\
\text { criteria: nurses } \\
\text { whose } \\
\text { screening } \\
\text { indicated } \\
\text { clinical level of } \\
\text { depression, } \\
\text { PTSD, } \\
\text { substance } \\
\text { abuse, or on } \\
\text { prescription for } \\
\text { mental health } \\
\text { conditions. }\end{array}$ & $\begin{array}{l}\text { MSCR consists of one day } \\
\text { CF prevention training } \\
\text { workshop, followed by } \\
\text { weekly mindfulness } \\
\text { training sessions for four } \\
\text { weeks and total of } 12 \\
\text { hours intervention. Nurses } \\
\text { completed standardized } \\
\text { tests at pre, post and one } \\
\text { month follow up. } \\
\text { Patient Health } \\
\text { Questionnaire-9 } \\
\text { (PHQ-9) is a valid clinical } \\
\text { depression screening tool, } \\
\text { Short Screening Scale for } \\
\text { DSM-IV Post Traumatic } \\
\text { Stress Disorder SSSP for } \\
\text { DSM-IV PTSD is a } \\
\text { reliable and valid tool for } \\
\text { screening of Post- } \\
\text { Traumatic Stress Disorder } \\
\text { (PTSD) symptoms, CAGE } \\
\text { questionnaire is a valid } \\
\text { tool to screen for alcohol } \\
\text { and substance misuse. All } \\
\text { the above three tools were } \\
\text { used to assess exclusion } \\
\text { criteria. } \\
\text { The ProQoL5is a validated } \\
\text { tool for psychometric } \\
\text { evaluation of nurses, it has } \\
\text { three subscales that } \\
\text { measure levels of }\end{array}$ & None & $\begin{array}{l}\text { Scores of pre-test, } \\
\text { post-test and one } \\
\text { month follow-up } \\
\text { assessment points. } \\
\text { Wilcoxon signed- } \\
\text { rank paired sample } \\
\text { test reflected } \\
\text { significant reductions } \\
\text { for depression, } \\
\text { burnout, and TNA } \\
\text { scores at post-test. } \\
\text { One month after the } \\
\text { intervention, } \\
\text { significant reductions } \\
\text { were maintained for } \\
\text { burnout and TNA, } \\
\text { but not depression } \\
\text { scores. } \\
\text { There was significant } \\
\text { improvement in } \\
\text { compassion } \\
\text { satisfaction from pre- } \\
\text { test to } 1 \text { month } \\
\text { follow-up. } \\
\text { There were no } \\
\text { significant } \\
\text { improvements for } \\
\text { both general } \\
\text { resilience and } \\
\text { harmonious passion } \\
\text { from pre-test to post- } \\
\text { test or at one-month } \\
\text { follow-up. }\end{array}$ & $\begin{array}{l}\text { Total of } 20 \text { nurses completed the study. The results } \\
\text { showed that increased awareness of CF including } \\
\text { MSCR improve resilience and well-being among } \\
\text { nurses. } \\
\text { Further research utilizing a control group and larger } \\
\text { samples are required to strengthen the conclusion. } \\
\text { Significant improvements were concluded } \\
\text { following the intervention for CF, burnout, trait- } \\
\text { negative affect, obsessive passion, and stress scores } \\
\text { at preintervention, } 45 \% \text { of sample had high burnout } \\
\text { scores, this reduced to } 15 \% \text { post-intervention. } \\
\text { No significant changes were observed for general } \\
\text { resilience, anxiety, or secondary traumatic stress } \\
\text { post-intervention. }\end{array}$ \\
\hline
\end{tabular}




\begin{tabular}{|c|c|c|c|c|c|c|}
\hline & & & $\begin{array}{l}\text { compassion satisfaction } \\
\text { and CF. CF is composed } \\
\text { of burnout and Secondary } \\
\text { Traumatic Stress (STS) } \\
\text { subscales. The reliabilities } \\
\text { at pre-intervention for } \\
\text { each subscale in this study } \\
\text { were compassion } \\
\text { satisfaction alpha=.89, } \\
\text { burnout alpha=.75, and } \\
\text { STS alpha =.60. } \\
\text { Passion for Work Scale } \\
\text { (PWS) measures } \\
\text { harmonious and obsessive } \\
\text { passion. } \\
\text { Statistical analyses were } \\
\text { performed with } \\
\text { IBM_Statistical Package } \\
\text { for the Social Sciences } \\
\text { (IBM-SPPS) window } \\
\text { version } 21 . \\
\text { Shapiro-Wilk tests were } \\
\text { used to examine study } \\
\text { variable distributions. } \\
\text { Wilcoxon Signed-rank } \\
\text { non parametric tests were } \\
\text { used to assess within } \\
\text { group changes for study } \\
\text { variables from pre to post } \\
\text { intervention and pre to } \\
\text { follow-up. }\end{array}$ & & & \\
\hline $\begin{array}{l}\text { Durkin, M., } \\
\text { Beaumont, E., } \\
\text { Martin, C. J. H., } \\
\text { \& Carson, J. } \\
\text { (2016). A pilot } \\
\text { study exploring } \\
\text { the relationship } \\
\text { between self- } \\
\text { compassion, } \\
\text { self-judgement, } \\
\text { self-kindness, } \\
\text { compassion, } \\
\text { professional }\end{array}$ & $\begin{array}{c}\text { Pilot Study } \\
\text { Cross sectional } \\
\text { questionnaire } \\
\text { survey } \\
\text { Level V } \\
\text { Grade B }\end{array}$ & $\begin{array}{l}\text { Quantitative } \\
\text { data were } \\
\text { collected from } \\
37 \text { nurses who } \\
\text { had clinical } \\
\text { experience and } \\
\text { were studying } \\
\text { for post- } \\
\text { graduate } \\
\text { diploma in UK. } \\
34 \text { females and } \\
3 \text { males. }\end{array}$ & $\begin{array}{l}\text { By utilizing the following } \\
\text { standardized scales to } \\
\text { measure the relationships } \\
\text { between self-compassion, } \\
\text { compassion fatigue, } \\
\text { wellbeing, and burnout. } \\
\text {-Compassion for Others } \\
\text { Scale (CFO) scale } \\
\text { measures how individuals } \\
\text { act toward others. Scale } \\
\text { validity was established } \\
\text { from data collected with }\end{array}$ & None & $\begin{array}{l}\text { To measure the } \\
\text { associations between } \\
\text { self-compassion, } \\
\text { compassion fatigue, } \\
\text { wellbeing, and } \\
\text { burnout in } \\
\text { community nurses in } \\
\text { the UK. } \\
\text { The following were } \\
\text { the research } \\
\text { instruments: } \\
\text { CFO scale } \\
\text { ProQOL }\end{array}$ & $\begin{array}{l}\text { Data were analyzed using SPSS version } 20 . \\
\text { Descriptive statistics were calculated before } \\
\text { inferential analyses using a Spearman's Rho } \\
\text { correlation and Mann Whitney Independent U test } \\
\text { from divided scores of high versus low. } \\
\text { Nurses who are more self- compassionate are less } \\
\text { likely to suffer from burnout., which is a } \\
\text { statistically significant negative relationship } \\
\text { between self-compassion and burnout. } \\
\text { Nurses who feel a greater sense of satisfaction from } \\
\text { their work show greater compassion, more positive } \\
\text { well-being, and are less prone to burnout. }\end{array}$ \\
\hline
\end{tabular}




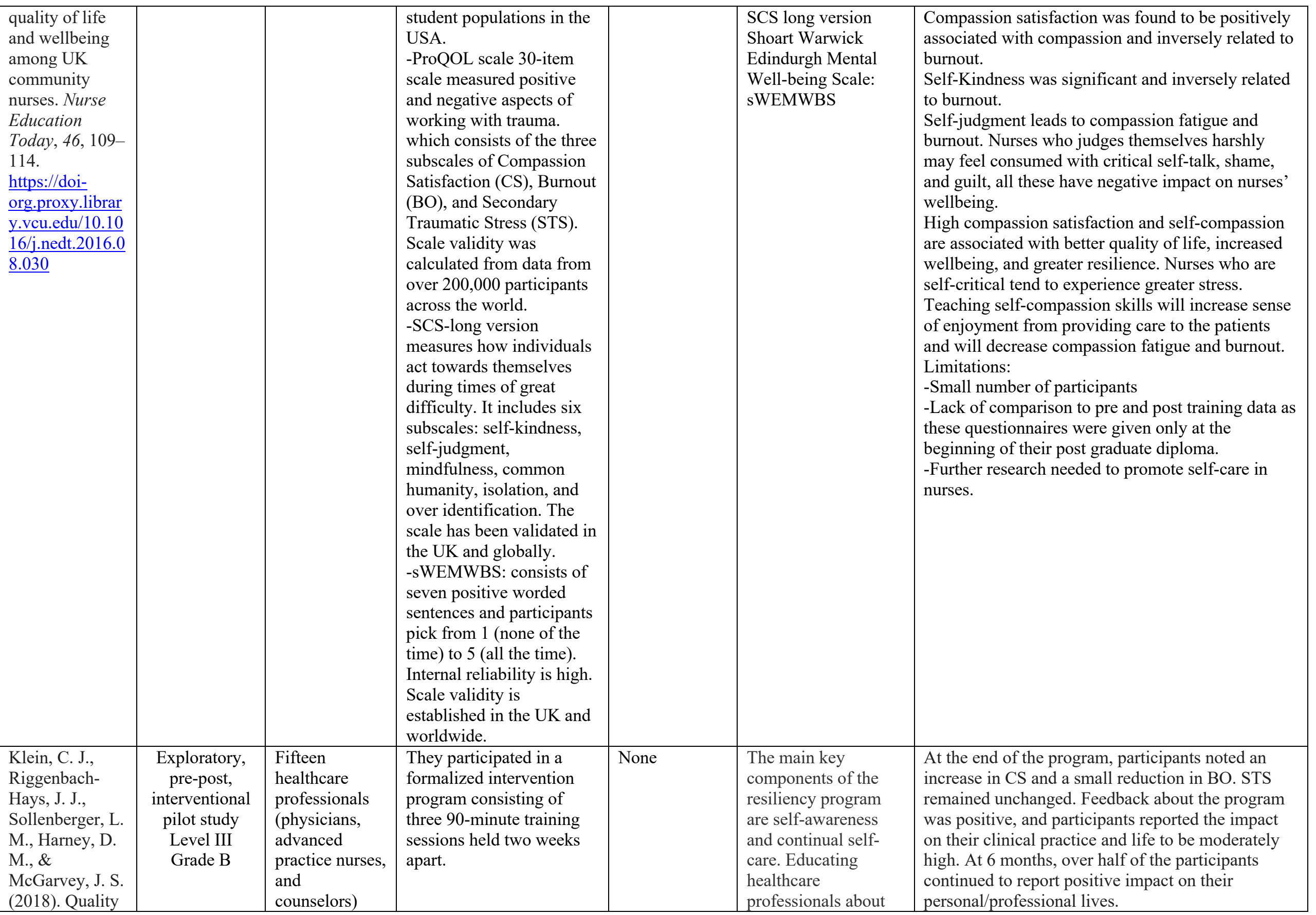




\begin{tabular}{|c|c|c|c|c|c|c|}
\hline $\begin{array}{l}\text { of life and } \\
\text { compassion } \\
\text { satisfaction in } \\
\text { clinicians: A } \\
\text { pilot } \\
\text { intervention } \\
\text { study for } \\
\text { reducing } \\
\text { compassion } \\
\text { fatigue. The } \\
\text { American } \\
\text { Journal of } \\
\text { Hospice \& } \\
\text { Palliative } \\
\text { Care, 35(6), } \\
\text { 882-888. } \\
\text { https://doi- } \\
\text { org.proxy.librar } \\
\text { y.vcu.edu/10.11 } \\
77 / 1049909117 \\
740848\end{array}$ & & $\begin{array}{l}\text { caring for } \\
\text { chronic, } \\
\text { acutely ill, or } \\
\text { patients who } \\
\text { might be } \\
\text { moving toward } \\
\text { comfort care. }\end{array}$ & & & $\begin{array}{l}\text { CF and by identifying } \\
\text { lifestyle strategies to } \\
\text { minimize BO. This } \\
\text { will assist healthcare } \\
\text { providers to maintain } \\
\text { the qualities } \\
\text { associated with } \\
\text { compassion } \\
\text { satisfaction. } \\
\text { The ProQOL5 was } \\
\text { used to measure } 3 \\
\text { separate concepts: } \\
\text { CS, BO, and STS } \\
\text { (CF). }\end{array}$ & $\begin{array}{l}\text { Limitations: } \\
\text { No control group } \\
\text { Small number of participants }\end{array}$ \\
\hline $\begin{array}{l}\text { Michael, S., } \\
\text { Villarreal, P.M., } \\
\text { Ferguson, M. } \\
\text { F., Willer, J. L., } \\
\text { Zane, R. D., } \\
\text { Flarity, K. } \\
\text { (2019). Virtual } \\
\text { reality-based } \\
\text { resilience } \\
\text { program. } \\
\text { Clinical Journal } \\
\text { of Oncology } \\
\text { Nursing, 23 (6). } \\
\text { 664-667. } \\
\underline{\text { https://doi.org/1 }} \\
\underline{0.1188 / 19 . C J O} \\
\text { N.664-667 }\end{array}$ & $\begin{array}{c}\text { Explanatory } \\
\text { quantitative } \\
\text { study } \\
\text { Level III } \\
\text { Grade B }\end{array}$ & $\begin{array}{l}24 \text { nurses from } \\
\text { Oncology unit } \\
\text { and eight } \\
\text { nurses from a } \\
\text { substance } \\
\text { abuse } \\
\text { treatment unit. } \\
\text { From the } 32 \\
\text { nurses, only } 27 \\
\text { nurses } \\
\text { completed } 56 \\
\text { virtual reality } \\
\text { (VR) based } \\
\text { relaxation } \\
\text { sessions. }\end{array}$ & $\begin{array}{l}\text { A } 6 \text { week study where } \\
\text { participants attended VR } \\
\text { sessions. At the end of } \\
\text { each session participants } \\
\text { were asked to perform a } 3 \\
\text { minute guided breathing } \\
\text { exercises to improve } \\
\text { relaxation. At the } \\
\text { conclusion of each } \\
\text { session, participants were } \\
\text { asked if they felt: better, } \\
\text { worse, or the same } \\
\text { compared to prior starting } \\
\text { the session. }\end{array}$ & None & $\begin{array}{l}\text { VR is an engaging } \\
\text { simulation to nurses } \\
\text { used in this study to } \\
\text { reduce CF and } \\
\text { burnout. } \\
\text { Resilience such as } \\
\text { self-care activities } \\
\text { may mitigate the } \\
\text { negative effect of CF. } \\
\text { Training hospital } \\
\text { nurses to practice } \\
\text { mindfulness, positive } \\
\text { self-talk, } \\
\text { communication } \\
\text { skills, and breathing } \\
\text { exercises are } \\
\text { associated with } \\
\text { improve performance } \\
\text { and decrease }\end{array}$ & $\begin{array}{l}\text { The majority of participants at the end of each VR } \\
\text { session reported improvement in mood }(\mathrm{n}=30 \text {, } \\
53 \%) \text {. } \\
\text { Post intervention survey of } 11 \text { participants }(41 \%) \\
\mathrm{n}=6 \text { which is } 55 \% \text { believed that VR sessions were } \\
\text { beneficial. } 10 \text { out of } 11 \text { participants }(91 \%) \text { reported } \\
\text { struggling to integrate VR sessions into their } \\
\text { breaks, or feeling guilty about spending time away } \\
\text { from their patients. Many nurses reported difficulty } \\
\text { using restroom or hydration. }\end{array}$ \\
\hline
\end{tabular}




\begin{tabular}{|c|c|c|c|c|c|}
\hline $\begin{array}{l}\text { Rajeswari, H., } \\
\text { Sreelekha, B. } \\
\text { K., Nappinai, } \\
\text { S., } \\
\text { Subrahmanyam, } \\
\text { U., \& } \\
\text { Rajeswari, V. } \\
\text { (2020). Impact } \\
\text { of accelerated } \\
\text { recovery } \\
\text { program on } \\
\text { compassion } \\
\text { fatigue among } \\
\text { nurses in South } \\
\text { India. Iranian } \\
\text { Journal of } \\
\text { Nursing and } \\
\text { Midwifery } \\
\text { Research, 25(3), } \\
\text { 249-253. } \\
\text { https://doi.org/1 } \\
\text { 0.4103/ijnmr.IJ } \\
\text { NMR 218 19 }\end{array}$ & $\begin{array}{l}\text { Experimental } \\
\text { Level I } \\
\text { High Quality } \\
\text { Grade A }\end{array}$ & $\begin{array}{l}120 \text { nurses } \\
\text { working in } \\
\text { Narayana } \\
\text { Medical } \\
\text { College } \\
\text { Hospital, India. } \\
\text { They were } \\
\text { divided } \\
\text { randomly to } 60 \\
\text { nurses in the } \\
\text { control and } 60 \\
\text { nurses in the } \\
\text { intervention } \\
\text { group. The } \\
\text { intervention } \\
\text { called } \\
\text { Accelerated } \\
\text { Recovery } \\
\text { Program } \\
\text { (ARP). } \\
\text { It is an } \\
\text { experimental } \\
\text { study }\end{array}$ & 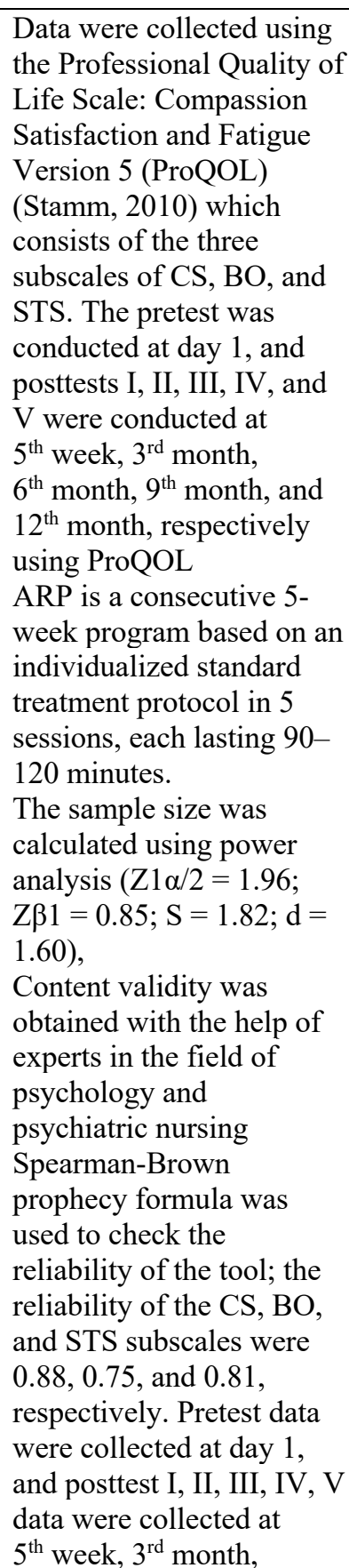 & $\begin{array}{l}\text { Regular practice of } \\
\text { ARP can enhance CS } \\
\text { and thus, reduce CF. } \\
\text { A professional } \\
\text { obligation exists for } \\
\text { nurses to strengthen } \\
\text { their CS and to } \\
\text { prevent, recognize, } \\
\text { and combat CF so } \\
\text { that they can continue } \\
\text { their work with the } \\
\text { presence it deserves. }\end{array}$ & $\begin{array}{l}\text { There was a statistically significant difference in the } \\
\text { ProQOL score between the intervention and control } \\
\text { groups, which demonstrated a significant difference } \\
\text { between the groups in terms of: } \\
\left.\text { CS ( } \mathrm{F}_{1,118}=120.10, p<0.001\right) \text {. } \\
\text { BO }\left(\mathrm{F}_{1,118}=123.11, p<0.001\right) \text {. } \\
\left.\text { STS ( } \mathrm{F}_{1,118}=205.18, p<0.001\right) \text {. } \\
\text { The mean score of BO and STS significantly } \\
\text { decrease and CS increased in the intervention group } \\
\text { compared to the control group. } \\
\text { ARP increased CS and reduced CF among nurses. } \\
\text { This study offered a follow-up until one year that } \\
\text { proved to help nurses to combat CF. } \\
\text { A program consisting of self-regulation, } \\
\text { intentionality, and CF interventions proved to be } \\
\text { efficient for the prevention and management of CF } \\
\text { in the post test at } 3 \text { and } 6 \text { months. } \\
\text { Limitations: } \\
\text {-This study offered an intervention package but the } \\
\text { effect of each intervention was not assessed. } \\
\text {-There was no way to put in consideration other } \\
\text { supports received from family, friends, colleagues } \\
\text { or superiors in the control or intervention group. } \\
\text { Additional studies needed on larger populations }\end{array}$ \\
\hline
\end{tabular}




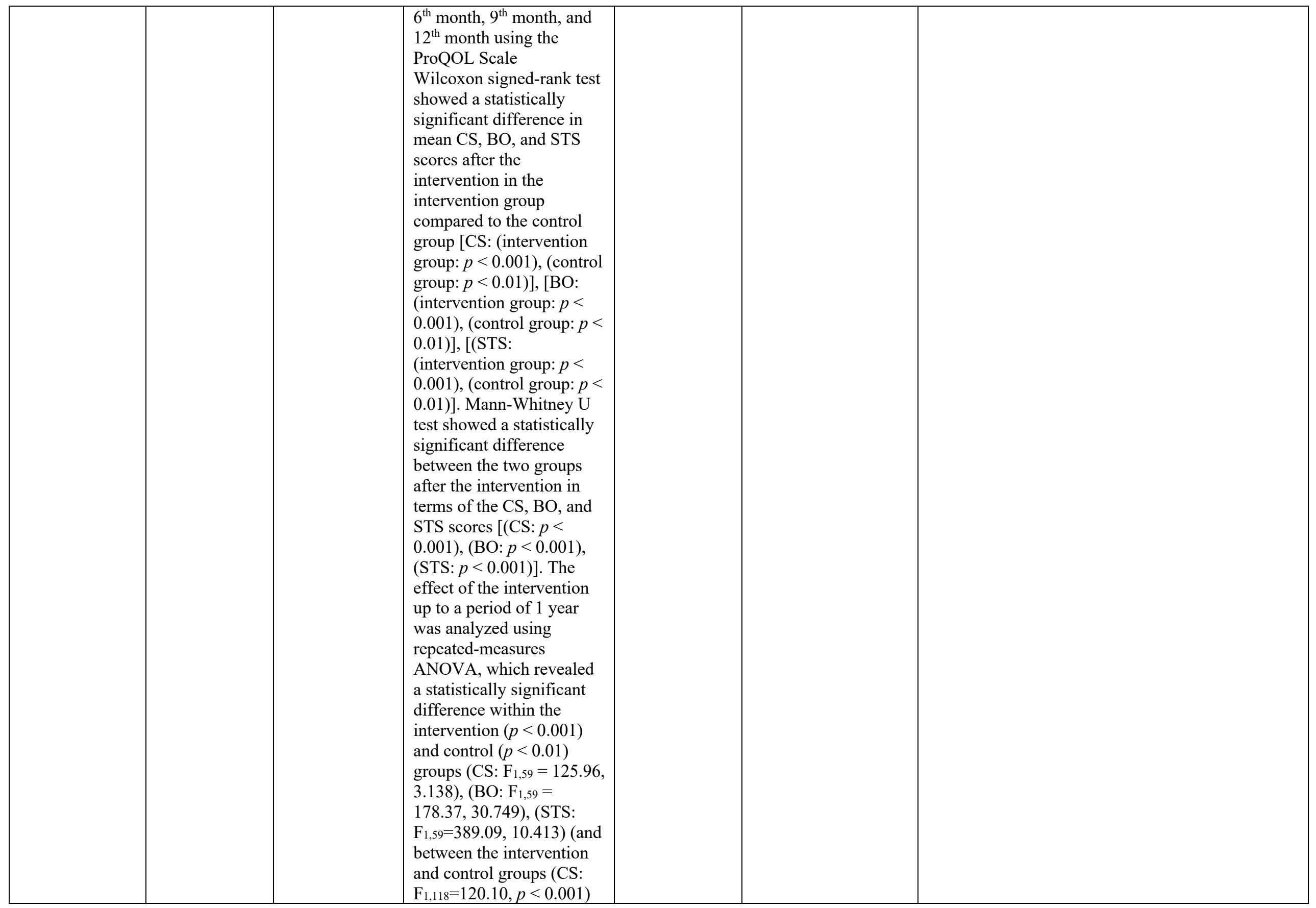




\begin{tabular}{|c|c|c|c|c|c|c|}
\hline & & & $\begin{array}{l}\left(\mathrm{BO}: \mathrm{F}_{1,118}=123.11, p<\right. \\
0.001)(\mathrm{STS}: \\
\left.\mathrm{F}_{1,118}=205.18, p<0.001\right)\end{array}$ & & & \\
\hline $\begin{array}{l}\text { Sullivan, C. E., } \\
\text { King, A. R., } \\
\text { Holdiness, J., } \\
\text { Durrell, J., } \\
\text { Roberts, K. K., } \\
\text { Spencer, C., } \\
\text { Roberts, J., } \\
\text { Ogg, S. W., } \\
\text { Moreland, M. } \\
\text { W., Browne, E. } \\
\text { K., Cartwright, } \\
\text { C., Crabtree, V. } \\
\text { M., Baker, J. N., } \\
\text { Brown, M., } \\
\text { Sykes, A., \& } \\
\text { Mandrell, B. N. } \\
\text { (2019). } \\
\text { Reducing } \\
\text { compassion } \\
\text { fatigue in } \\
\text { inpatient } \\
\text { pediatric } \\
\text { oncology } \\
\text { nurses. Oncolog } \\
\text { y Nursing } \\
\text { Forum, 46(3), } \\
\text { 338-347. } \\
\text { https://doi- } \\
\text { org.proxy.librar } \\
\text { y.vcu.edu/10.11 } \\
\text { 88/19.ONF.338- } \\
\text { 347 }\end{array}$ & $\begin{array}{l}\text { Quality } \\
\text { improvement } \\
\text { pilot study . } \\
\text { Level III } \\
\text { Grade B }\end{array}$ & $\begin{array}{l}\text { Despite } 59 \\
\text { pediatric } \\
\text { oncology } \\
\text { nurses were } \\
\text { originally } \\
\text { enrolled, only } \\
37 \text { participants } \\
\text { completed all } \\
\text { outcome } \\
\text { measures. }\end{array}$ & $\begin{array}{l}\text { Validated measures of: } \\
\text {-CF and CS through } \\
\text { ProQOL V } \\
\text {-Coping through brief } \\
\text { COPE } \\
\text {-Resilience through } \\
\text { Connor-Davidson } \\
\text { Resilience Scale-2 } \\
\text { Were evaluated pre- } \\
\text { training program, at } 2,4 \\
\text { and } 6 \text { months post } \\
\text { program. } \\
\text {-Demographic variables } \\
\text { were collected. } \\
\text { ProQOL: } 30 \text {-item self- } \\
\text { report scale that is } \\
\text { commonly used to assess } \\
\text { the impact of helping in } \\
\text { caring professionals. } \\
\text { Scores are reported as raw } \\
\text { score (allow for better } \\
\text { analysis of continuous } \\
\text { data) or t scores (provide } \\
\text { standardized scoring). } \\
\text { Connor-Davidson } \\
\text { Resilience Scale- } 2 \text { : } \\
\text { composed of } 2 \text {-item, } 4 \\
\text { point Likert-type } \\
\text { assessment of personal } \\
\text { resilience characteristics } \\
\text { and symptom status. } \\
\text { Brief COPE Scale: } \\
\text { composed of } 28 \text {-item } \\
\text { questionnaire to assess } \\
\text { adult coping strategies that } \\
\text { measures coping reactions } \\
\text { through } 12 \text { two-item } \\
\end{array}$ & $\begin{array}{l}\text { The Neuman } \\
\text { Systems } \\
\text { Model was } \\
\text { utilized as the } \\
\text { theoretical } \\
\text { framework. } \\
\text { This model } \\
\text { describes the } \\
\text { individual as a } \\
\text { whole client } \\
\text { who interacts } \\
\text { with actual or } \\
\text { perceived } \\
\text { stressors. } \\
\text { According to } \\
\text { this model, } \\
\text { individuals use } \\
\text { protective } \\
\text { mechanism to } \\
\text { cope and } \\
\text { achieve } \\
\text { wellbeing. In } \\
\text { this model, CF } \\
\text { can be the } \\
\text { result of the } \\
\text { depletion of } \\
\text { one's core } \\
\text { energy due to } \\
\text { ineffective } \\
\text { coping and } \\
\text { resilience } \\
\text { against } \\
\text { stressors. On } \\
\text { the other hand, } \\
\text { CS reflects } \\
\text { wellbeing and } \\
\text { resilience as a } \\
\end{array}$ & $\begin{array}{l}\text { Unit-Based Self-Care } \\
\text { Program } \\
\text { Intervention: } \\
\text {-Training } \\
\text {-Health and wellness: } \\
\text { nutrition, exercise, } \\
\text { sleep } \\
\text {-Grief and } \\
\text { bereavement: end of } \\
\text { life debriefing and } \\
\text { remembrance } \\
\text { activities. } \\
\text {-Respite room. } \\
\text { The Wilcoxon } \\
\text { signed-rank test was } \\
\text { used to compare the } \\
\text { change in ProQOLV } \\
\text { scores from baseline, } \\
\text { to the following: } 2 \\
\text { months, } 4 \text { months, } \\
\text { and } 6 \text { months. } \\
\text { The Spearman rank } \\
\text { correlation } \\
\text { coefficient was used } \\
\text { to assess the } \\
\text { relationship between } \\
\text { quality of life scores } \\
\text { and resilience and } \\
\text { coping style scores at } \\
\text { baseline and at } 6 \\
\text { months. }\end{array}$ & $\begin{array}{l}\text { The organizational support and the intervention can } \\
\text { reduce CF and increase CS. } \\
\text { Adaptive coping styles should be fostered to } \\
\text { facilitate CS and protect against CF. } \\
\text { Staff may require additional support in combating } \\
\text { CF during the holidays due to patient acuity, } \\
\text { staffing schedules, and less experienced nurses } \\
\text { working holiday hours. } \\
\text { Additional work is recommended to explore the role } \\
\text { of coping, resilience, and organizational support to } \\
\text { reduce CF. } \\
\text { Pediatric oncology nurses are susceptible to CF. } \\
\text { Through the six month pilot program, nurses's CF } \\
\text { levels were reduced, reflecting the benefit of CF } \\
\text { program } \\
\text { In ProQOLV scores: } 81 \% \text { of nurses had } \\
\text { comparative outcomes from baseline to } 2 \text { months, } \\
83 \% \text { had comparative outcomes from baseline to } 4 \\
\text { months, and } 69 \% \text { had comparative outcomes from } \\
\text { baseline to } 6 \text { months. } \\
\text { A statistically significant p=0.029 reduction in in } \\
\text { secondary traumatic stress from baseline to } 4 \\
\text { months. }\end{array}$ \\
\hline
\end{tabular}




\begin{tabular}{|c|c|c|c|c|c|c|}
\hline & & & $\begin{array}{l}\text { subscales. Coping reaction } \\
\text { is ranked through a four- } \\
\text { point Likert scale from } 1 \\
\text { to } 4 \text {, with higher score } \\
\text { indicates endorsing of } \\
\text { coping trait. }\end{array}$ & $\begin{array}{l}\text { result of } \\
\text { adaptive } \\
\text { coping. This } \\
\text { framework is } \\
\text { focused on } \\
\text { nurses' } \\
\text { wellness, } \\
\text { resilience and } \\
\text { depletion of } \\
\text { core energy. }\end{array}$ & & \\
\hline $\begin{array}{l}\text { Yilmaz, G., } \\
\text { Üstün, B., \& } \\
\text { Günüssen, N. P. } \\
\text { (2018). Effect } \\
\text { of a nurse-led } \\
\text { intervention } \\
\text { programme on } \\
\text { professional } \\
\text { quality of life } \\
\text { and post- } \\
\text { traumatic } \\
\text { growth in } \\
\text { oncology } \\
\text { nurses. Internati } \\
\text { onal Journal of } \\
\text { Nursing } \\
\text { Practice, 24(6), } \\
\text { e12687. } \\
\text { https://doi.org/1 } \\
\underline{0.1111 / \text { ijn.1268 }} \\
\underline{7}\end{array}$ & $\begin{array}{l}\text { Non- } \\
\text { experimental } \\
\text { single group } \\
\text { study with pre- } \\
\text { test and post- } \\
\text { test } \\
\text { comparisons. } \\
\text { Level III } \\
\text { Grade B }\end{array}$ & $\begin{array}{l}43 \text { hospital } \\
\text { nurses who } \\
\text { care for } \\
\text { oncology } \\
\text { patients, and } \\
\text { work in } \\
\text { oncology, } \\
\text { chemotherapy, } \\
\text { pediatric } \\
\text { oncology, } \\
\text { chest disease } \\
\text { clinics, internal } \\
\text { medicine clinic } \\
\text { and ear nose } \\
\text { and throat } \\
\text { clinic } \\
\text { in the } \\
\text { University } \\
\text { Hospital in } \\
\text { Izmir, Turkey } \\
\text { There are three } \\
\text { main } \\
\text { hypotheses in } \\
\text { this study: } \\
\text {-Nurses' } \\
\text { compassion } \\
\text { fatigue and } \\
\text { burnout score } \\
\text { will be lower } \\
\text { than before the } \\
\text { intervention } \\
\text {-Nurses' } \\
\text { compassion }\end{array}$ & $\begin{array}{l}\text { A nurse-led intervention } \\
\text { program consisted of two } \\
\text { face-to-face sessions } \\
\text { (lecture, reading and video } \\
\text { about CF and coping, } \\
\text { exercise, baksi dance, } \\
\text { mandala painting) and two } \\
\text { counseling follow-up } \\
\text { sessions by phone } \\
\text { (motivational messages } \\
\text { via smart phone). } \\
\text { Instruments: } \\
\text {-Information form for } \\
\text { nurses: age, gender, } \\
\text { marital status, number of } \\
\text { children, education level, } \\
\text { oncology training, years as } \\
\text { a nurse, years working } \\
\text { with cancer patients, } \\
\text { occupation status and } \\
\text { number of hours working } \\
\text { per week, willingness to } \\
\text { choose nursing, and } \\
\text { willingness to work with } \\
\text { oncology patients. } \\
\text {-ProQOL-IV: } \\
\text { This scale was developed } \\
\text { to measure compassion } \\
\text { satisfaction, compassion } \\
\text { fatigue, and burnout } \\
\text { symptoms. } \\
\text { The scale is composed of } \\
\text { 10-item scales. }\end{array}$ & None & $\begin{array}{l}\text { To determine the } \\
\text { effectiveness of a } \\
\text { nurse-led intervention } \\
\text { program on ProQOL } \\
\text { and Post Traumatic } \\
\text { Growth Inventory } \\
\text { (PTGI). } \\
\text { The sample size was } \\
\text { predetermined by } \\
\text { using a power } \\
\text { calculation with the } \\
\text { G-POWER } 3.1 \\
\text { software analysis } \\
\text { program. The power } \\
\text { calculation was based } \\
\text { on a medium effect } \\
\text { size (0.5), an alpha of } \\
0.05 \text { and a power of } \\
0.80 \text {. The sample size } \\
\text { desired was } 50 \\
\text { participants and only } \\
43 \text { nurses agreed to } \\
\text { participate. The } \\
\text { power of } 0.99 \text { was } \\
\text { determined at } 0.8 \\
\text { effect size (large), an } \\
\text { alpha of } 0.05 \text { for the } \\
\text { difference from the } \\
\text { constant in a one } \\
\text { sample case using t } \\
\text { tests (n=43). }\end{array}$ & $\begin{array}{l}\text { The nurse-led intervention program concluded that } \\
\text { there was a decrease in post-intervention in nurses' } \\
\text { scores for compassion fatigue and burnout, and an } \\
\text { increase in compassion satisfaction. The ProQOL- } \\
\text { IV reflected a p value }<0.01 \text { from pre to post- } \\
\text { intervention in the three subscales of compassion } \\
\text { fatigue, burnout, and compassion satisfaction. The } \\
\text { PTGI reflected a p value of }<0.01 \text { from pre to post- } \\
\text { intervention in the three listed dimensions. P value } \\
\text { is significant as }<0.05 \text {. } \\
\text { Limitations of the study: } \\
\text { The research sample consisted mostly of female } \\
\text { nurses. } \\
\text { It could be some biased as the participant nurses } \\
\text { knew the purpose of the study and the nurse led the } \\
\text { intervention was the researcher herself. } \\
\text { Conclusion: } \\
\text { Nurse-led intervention was effective in decreasing } \\
\text { CF and burnout of oncology nurses and increasing } \\
\text { compassion satisfaction and for transforming } \\
\text { traumatic experiences into PTGI. }\end{array}$ \\
\hline
\end{tabular}




\begin{tabular}{|c|c|c|c|c|c|c|}
\hline & & $\begin{array}{l}\text { satisfaction } \\
\text { score will be } \\
\text { higher than } \\
\text { before the } \\
\text { intervention } \\
\text {-Nurses will } \\
\text { have a higher } \\
\text { score on all } \\
\text { subscales and } \\
\text { total scores of } \\
\text { the post- } \\
\text { traumatic } \\
\text { growth } \\
\text { inventory than } \\
\text { before the } \\
\text { intervention. }\end{array}$ & $\begin{array}{l}\text { Compassion satisfaction } \\
\text { ( } \alpha=0.87 \text { ) is defined as the } \\
\text { pleasure derived from } \\
\text { being able to do your work } \\
\text { well. } \\
\text { Burnout ( } \alpha=0.72 \text { ) is } \\
\text { defined as feelings of } \\
\text { hopelessness and } \\
\text { difficulties in dealing with } \\
\text { work or doing a job } \\
\text { effectively. } \\
\text { Secondary traumatic stress } \\
\text { or compassion fatigue ( } \alpha= \\
\text { 0.80) is defined as work- } \\
\text { related secondary } \\
\text { exposure to extremely } \\
\text { stressful events. } \\
\text {-PTGI: } \\
\text { This inventory was } \\
\text { developed to evaluate the } \\
\text { positive effects in } \\
\text { individuals after their } \\
\text { exposure to traumatic } \\
\text { experiences. High scores } \\
\text { for PTGI are signs of } \\
\text { growth. The inventory was } \\
\text { adapted into three } \\
\text { dimensions: changed } \\
\text { interpersonal relationships } \\
\text { ( } \alpha=0.70 \text { ), changed } \\
\text { philosophy of life } \\
\text { ( } \alpha=0.78 \text { ), and changed } \\
\text { perception of self } \\
\text { ( } \alpha=0.82 \text { ). }\end{array}$ & & & \\
\hline $\begin{array}{l}\text { Zajac, L. M., } \\
\text { Moran, K. J., \& } \\
\text { Groh, C. J. } \\
\text { (2017). } \\
\text { Confronting } \\
\text { compassion } \\
\text { fatigue: } \\
\text { Assessment and } \\
\text { intervention in } \\
\text { inpatient }\end{array}$ & $\begin{array}{l}\text { Mixed } \\
\text { methods } \\
\text { sequential } \\
\text { design study } \\
\text { Level III } \\
\text { Grade B }\end{array}$ & $\begin{array}{l}107 \text { of } 183 \\
(58 \%) \\
\text { participants } \\
\text { returned } \\
\text { preintervention } \\
\text { survey (nurses } \\
\text { and assistive } \\
\text { personnel) } \\
\text { from medical } \\
\text { (hematology/bl }\end{array}$ & $\begin{array}{l}\text { Preintervention survey } \\
\text { including demographic } \\
\text { questions and ProQOL } \\
\text { scale. } \\
\text { Debriefing session after } \\
\text { each patient's death was } \\
\text { performed composed of } \\
\text { three questions related to } \\
\text { patient care, based on }\end{array}$ & $\begin{array}{l}\text { Morse's praxis } \\
\text { theory of } \\
\text { suffering was } \\
\text { used to } \\
\text { understand the } \\
\text { staff grief } \\
\text { process of } \\
\text { patient's death. } \\
\text { According to } \\
\text { Morse' theory }\end{array}$ & $\begin{array}{l}\text { This quality } \\
\text { improvement project } \\
\text { has } 2 \text { goals: support } \\
\text { the staff during the } \\
\text { time they are } \\
\text { experiencing grief } \\
\text { after the patient's } \\
\text { death, and to } \\
\text { decrease staff CF and } \\
\text { increase patient }\end{array}$ & $\begin{array}{l}\text { The quantitative part of the study reflected } \\
\text { improvement near ideal with lower burnout, } \\
\text { secondary traumatic stress, and CF. } \\
\text { Staff members who participated in the debriefings } \\
\text { were } 25 \text { and reported that it was helpful. About } \\
30 \% \text { of the staff who participated in the debriefings } \\
\text { selected neutral option, therefore, future studies. } \\
\text { ProQOL scores were average at baseline, which left } \\
\text { a narrow margin for improvement; therefore, }\end{array}$ \\
\hline
\end{tabular}




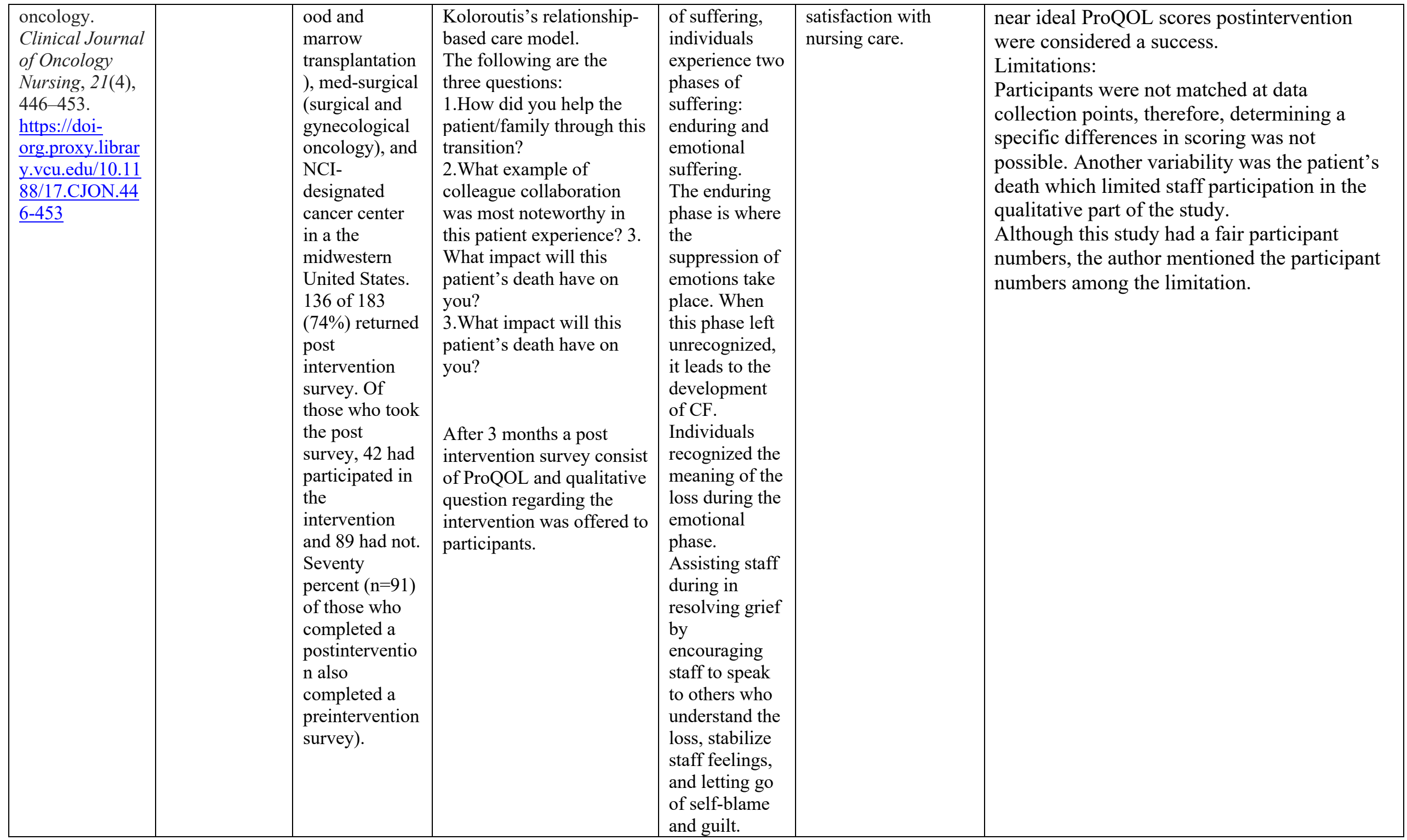




\section{Appendix B}

\section{Summary of Systematic Reviews}

\begin{tabular}{|c|c|c|c|c|c|c|c|}
\hline Citation & $\begin{array}{l}\text { Quality } \\
\text { Grade }\end{array}$ & Question & Search Strategy & $\begin{array}{l}\text { Inclusion/ } \\
\text { Exclusion Criteria }\end{array}$ & $\begin{array}{l}\text { Data Extraction and } \\
\text { Analysis }\end{array}$ & Key Findings & $\begin{array}{l}\text { Usefulness/Recommendation/ } \\
\text { Implications }\end{array}$ \\
\hline
\end{tabular}




\begin{tabular}{|c|c|c|c|c|c|c|c|}
\hline Citation & Quality & Question & Search Strategy & 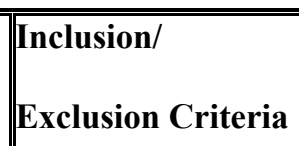 & $\begin{array}{l}\text { Data Extraction and } \\
\text { Analysis }\end{array}$ & Key Findings & $\begin{array}{l}\text { Usefulness/Recommendation/ } \\
\text { Implications }\end{array}$ \\
\hline & & & & & $\begin{array}{l}\text { and high burnout, and } \\
\text { medium and high } \\
\text { compassion fatigue. } \\
\text {-Publication bias was } \\
\text { evaluated with Egger } \\
\text { test and } \\
\text { heterogenicity with } \\
\text { I2. }\end{array}$ & $\begin{array}{l}\text { CF. Four studies applied } \\
\text { an intervention with pre- } \\
\text { test and posttest } \\
\text { measures, one study had } \\
\text { a follow-up at } 3 \text { and } 6 \\
\text { months. } \\
\text { The following is the } \\
\text { summary of the types of } \\
\text { the intervention: } \\
\text { Six weeks with a } \\
\text { duration of two hour per } \\
\text { week for each session on } \\
\text { mindfulness with } 15 \\
\text { minutes meditation per } \\
\text { day. Results showed } \\
\text { lower scores in CF and } \\
\text { burnout, and higher } \\
\text { levels of satisfaction in } \\
\text { life, mindfulness, and } \\
\text { self-compassion } \\
\text { Another intervention } \\
\text { was individual session, } \\
\text { CD with short term } \\
\text { meditation which led to } \\
\text { decrease CF and burnout } \\
\text { scores and increase } \\
\text { compassion satisfaction. } \\
\text { Another intervention } \\
\text { was a mobile app called } \\
\text { PRMA to promote } \\
\text { resilience for } 6 \text { weeks. } \\
\text { Resilience program } \\
\text { consisted of four } \\
\text { sessions of } 90 \text { minutes } \\
\text { each held during } \\
\text { working hours that led to } \\
\text { improving score in } \\
\text { compassion satisfaction, } \\
\text { burnout and secondary } \\
\text { traumatic stress. }\end{array}$ & \\
\hline
\end{tabular}




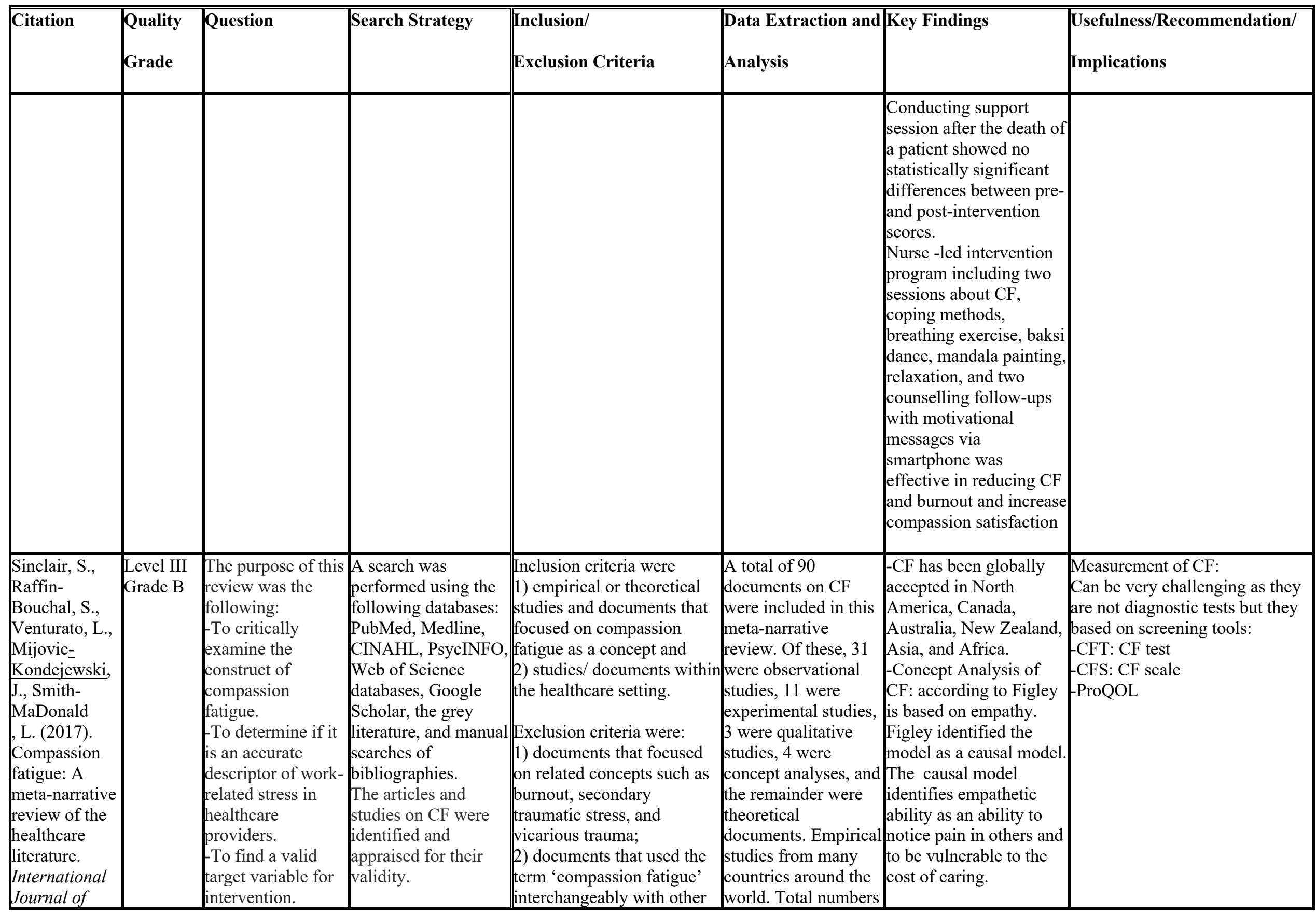




\begin{tabular}{|c|c|c|c|c|c|c|c|}
\hline Citation & $\begin{array}{l}\text { Quality } \\
\text { Grade }\end{array}$ & Question & Search Strategy & $\begin{array}{l}\text { Inclusion/ } \\
\text { Exclusion Criteria }\end{array}$ & $\begin{array}{l}\text { Data Extraction and } \\
\text { Analysis }\end{array}$ & Key Findings & $\begin{array}{l}\text { Usefulness/Recommendation/ } \\
\text { Implications }\end{array}$ \\
\hline $\begin{array}{l}\text { Nursing } \\
\text { Studies, 69, 9- } \\
24 . \\
\text { https://doi.org/ } \\
10.1016 / \text { j.ijnur } \\
\text { stu.2017.01.00 } \\
\underline{3}\end{array}$ & & & $\begin{array}{l}\text { Sources were mapped } \\
\text { according to the } \\
\text { following criteria: } \\
\text { 1) definitions; } \\
\text { 2) conceptual } \\
\text { analyses; } \\
\text { 3) signs and } \\
\text { symptoms; } \\
\text { 4) measures; } \\
\text { 5) prevalence and } \\
\text { associated risk } \\
\text { factors; and } \\
\text { 6) interventions. A } \\
\text { narrative account of } \\
\text { included studies that } \\
\text { critically examines } \\
\text { the concept of } \\
\text { compassion fatigue in } \\
\text { healthcare was } \\
\text { employed, and } \\
\text { recommendations for } \\
\text { practice, policy and } \\
\text { further research were } \\
\text { made. }\end{array}$ & $\begin{array}{l}\text { descriptors of work-related } \\
\text { stress in healthcare } \\
\text { providers; } \\
\text { 3) documents in social } \\
\text { workers, first responders, } \\
\text { educators, and family } \\
\text { caregivers; and } \\
\text { 4) letters, commentaries, } \\
\text { editorials, and conference } \\
\text { abstracts. }\end{array}$ & $\begin{array}{l}\text { of nurses from all } \\
\text { studies were 2444, } \\
\text { from all different } \\
\text { specialties. } \\
\\
\text { The following } \\
\text { concepts were } \\
\text { extracted: } \\
\text { 1) Defining CF } \\
\text { 2) Conceptual } \\
\text { analysis of CF } \\
\text { 3) Symptoms of CF } \\
\text { 4) Measurement of } \\
\text { CF } \\
\text { 5) Prevalence of CF } \\
\text { and associated risk } \\
\text { factors } \\
\text { 6) Intervention } \\
\text { programs }\end{array}$ & $\begin{array}{l}\text { CF originates from } \\
\text { disruption in empathy. } \\
\text { identified factors that } \\
\text { contribute to compassion } \\
\text { fatigue, including } \\
\text { caregiver exposure to } \\
\text { suffering; continuous } \\
\text { and intense contact with } \\
\text { patients; high-stress } \\
\text { environments; and high } \\
\text { therapeutic use of the } \\
\text { self in providing care-- } \\
\text { interjecting caregiver's } \\
\text { personhood into clinical } \\
\text { encounters. } \\
\text { CF can be "the final } \\
\text { result of a progressive } \\
\text { and cumulative process } \\
\text { that evolves from } \\
\text { compassion stress after a } \\
\text { period of unrelieved } \\
\text { compassion discomfort, } \\
\text { which is caused by } \\
\text { prolonged, continuous, } \\
\text { and intense contact with } \\
\text { patients, the use of self, } \\
\text { and exposure to stress" } \\
\text { Coetzee and Klopper, } \\
\text { 2010, p. 239). } \\
\text {-CF can manifest as } \\
\text { physical, behavioral, } \\
\text { psychological, and } \\
\text { spiritual. } \\
\text { Physical symptoms of } \\
\text { CF include: exhaustion, } \\
\text { insomnia, compromised } \\
\text { immunity, somatization, } \\
\text { headaches, stomach } \\
\text { aches, sleep disturbance, } \\
\text { fatigue, emotional }\end{array}$ & \\
\hline
\end{tabular}




\begin{tabular}{|c|c|c|c|c|c|c|c|}
\hline Citation & Quality & Question & Search Strategy & 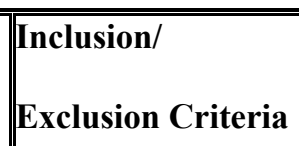 & \begin{tabular}{|l|} 
Data Extraction and \\
Analysis
\end{tabular} & Key Findings & $\begin{array}{l}\text { Usefulness/Recommendation/ } \\
\text { Implications }\end{array}$ \\
\hline & & & & & & \begin{tabular}{||l} 
exhaustion, and \\
hypochondria \\
Behavioral symptoms of \\
CF include: increased \\
alcohol intake (and other \\
drugs), anger and \\
irritability, strained \\
personal relationships, \\
absenteeism, attrition, \\
avoidance of patients, \\
impaired clinical \\
decision making, \\
compromised patient \\
care. \\
Psychological symptoms \\
of CF include: emotional \\
exhaustion, relational \\
distancing, negative self- \\
image, depression, \\
reduced ability to feel \\
sympathy and empathy, \\
cynicism, resentment, \\
dread of working with \\
certain patients, \\
professional \\
helplessness, diminished \\
enjoyment/career \\
satisfaction, \\
depersonalization, fear, \\
fractured world view, \\
heightened anxiety, \\
irrational fears, \\
increased personal \\
vulnerability, problems \\
with intimacy, intrusive \\
imagery, avoidance, \\
insensitivity or \\
hypersensitivity to \\
emotionally charged \\
stimuli, loss of hope,
\end{tabular} & \\
\hline
\end{tabular}




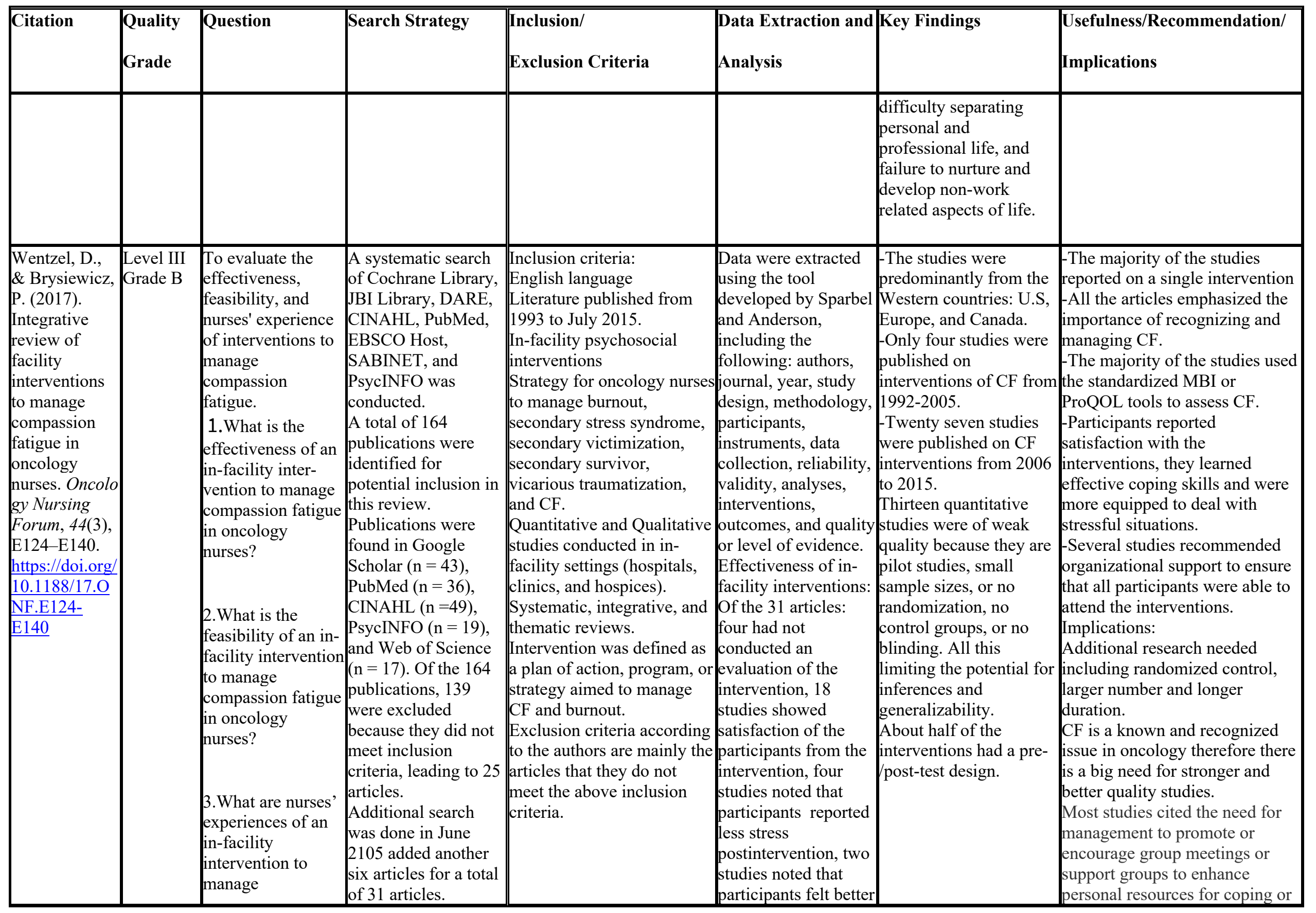




\begin{tabular}{|c|c|c|c|c|c|c|c|}
\hline Citation & Quality & Question & Search Strategy & 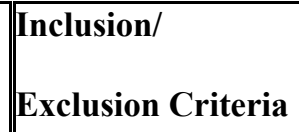 & $\begin{array}{l}\text { Data Extraction and } \\
\text { Analysis }\end{array}$ & Key Findings & $\begin{array}{l}\text { Usefulness/Recommendation/ } \\
\text { Implications }\end{array}$ \\
\hline & & $\begin{array}{l}\text { compassion } \\
\text { fatigue? }\end{array}$ & $\begin{array}{l}\text { Two reviewers } \\
\text { independently } \\
\text { appraised the studies. } \\
\text { Any conflict would } \\
\text { have passed to a third } \\
\text { reviewed, authors } \\
\text { said that a third } \\
\text { reviewer was not } \\
\text { needed. }\end{array}$ & & $\begin{array}{l}\text { and were able to offer } \\
\text { support to patients } \\
\text { and their caregivers. } \\
\text { Thirteen studies } \\
\text { described that } \\
\text { participants' } \\
\text { experiences of } \\
\text { rejuvenation, feelings } \\
\text { of being appreciated, } \\
\text { coping with job } \\
\text { difficulties, and the } \\
\text { value of peer support } \\
\text { groups. } \\
\text { Feasibility of in- } \\
\text { facility interventions: } \\
\text { There was a big } \\
\text { variation in the } \\
\text { timing and number of } \\
\text { interventions: } \\
\text { One-off sessions } \\
\text { (n=5) } \\
\text { Retreats from } 4 \text { hours } \\
\text { to } 1 \text { day ( } \mathrm{n}=5 \text { ). } \\
\text { Multiple sessions (2- } \\
\text { 10) varying from } 3 \\
\text { weeks to } 6 \text { months } \\
\text { (n=18). } \\
\text { Wide variety of } \\
\text { interventions: } \\
\text { Relaxation (yoga, } \\
\text { massage) (n=10) } \\
\text { Self-care and self- } \\
\text { reflection ( } \mathrm{n}=6 \text { ) } \\
\text { Emotional and } \\
\text { experiential } \\
\text { exchanges in small } \\
\text { groups ( }=5 \text { ). } \\
\text { Other interventions } \\
\text { include: }\end{array}$ & & $\begin{array}{l}\text { to create a balance between } \\
\text { professional and personal life } \\
\text { that would prevent or reduce } \\
\text { compassion fatigue in oncology } \\
\text { nurses }\end{array}$ \\
\hline
\end{tabular}




\begin{tabular}{|c|c|c|c|c|c|c|c|}
\hline Citation & Quality & Question & Search Strategy & $\begin{array}{l}\text { Inclusion/ } \\
\text { Exclusion Criteria }\end{array}$ & \begin{tabular}{|l||} 
Data Extraction and \\
Analysis
\end{tabular} & Key Findings & $\begin{array}{l}\text { Usefulness/Recommendation/ } \\
\text { Implications }\end{array}$ \\
\hline & & & & & \begin{tabular}{|l||} 
coping skills and \\
stress management, \\
role playing, \\
debriefing, problem \\
solving, bereavement \\
care, journals, music \\
therapy, sleep \\
hygiene, mobile \\
phone to cope with \\
stress, play therapy, \\
spiritual care, \\
mindfulness, \\
storytelling, short \\
essays, humor, work- \\
life balance, meaning \\
of life, wellness \\
plans, short films, \\
psychodrama \\
techniques, and \\
cognitive behavioral \\
therapy.
\end{tabular} & & \\
\hline $\begin{array}{l}\text { Xu, H., } \\
\text { Kynoch, K., } \\
\text { Tuckett, A., } \\
\text { Eley, R. } \\
\text { (2020). } \\
\text { Effectiveness } \\
\text { of } \\
\text { interventions } \\
\text { to reduce } \\
\text { emergency } \\
\text { department } \\
\text { staff } \\
\text { occupational } \\
\text { stress and/or } \\
\text { burnout: A } \\
\text { systematic } \\
\end{array}$ & \begin{tabular}{|l} 
Level IV \\
High \\
Quality A
\end{tabular} & $\begin{array}{l}\text { What is the } \\
\text { effectiveness of } \\
\text { interventions to } \\
\text { reduce } \\
\text { occupational stress } \\
\text { and/or burnout } \\
\text { among ED staff? }\end{array}$ & $\begin{array}{l}\text { A three-step search } \\
\text { strategy was utilized } \\
\text { to search seven } \\
\text { databases (PubMed, } \\
\text { CINAHL, Cochrane } \\
\text { Central Register of } \\
\text { Controlled Trials, } \\
\text { Embase, Scopus, } \\
\text { PsycINFO, Web of } \\
\text { Science) and five } \\
\text { gray literature } \\
\text { resources (MedNar, } \\
\text { Google Scholar, } \\
\text { ProQuest } \\
\text { Dissertations and }\end{array}$ & \begin{tabular}{|l} 
All health personnel \\
working in EDs, such as \\
physicians, nurses, and \\
allied health and \\
administrative staff. Any \\
hospital setting providing \\
emergency care, irrespective \\
of size, was considered for \\
inclusion, such as large \\
tertiary hospitals or small \\
rural remote hospitals. There \\
was no restriction regarding \\
participants' educational \\
levels or years of clinical \\
experience.
\end{tabular} & \begin{tabular}{|l||} 
Two reviewers \\
independently \\
extracted data from \\
the included studies \\
using the \\
standardized JBI data \\
extraction tool in JBI \\
SUMARI.74 The \\
extracted data \\
included specific \\
details about the \\
populations, methods, \\
interventions, and \\
outcomes of \\
significance to the
\end{tabular} & \begin{tabular}{|l} 
Interventions and MBIs \\
have potential to reduce \\
occupational stress and \\
burnout in staff working \\
in the ED. However, the \\
certainty of evidence \\
was considered as low \\
per the grading of \\
recommendations, \\
assessment, \\
development, and \\
evaluation (GRADE) \\
criteria due to limitations \\
in study designs, \\
indirectness of evidence, \\
and publication bias.
\end{tabular} & $\begin{array}{l}\text { Occupational stress and BO have } \\
\text { a negative impact on the well- } \\
\text { being of ED staff; it is crucial } \\
\text { that ED staff have access to } \\
\text { evidence-based interventions to } \\
\text { reduce stress and BO. } \\
\text { There is a need for future RCT } \\
\text { with large sample size in } \\
\text { assessing compassion fatigue } \\
\text { and effect of different } \\
\text { interventions. }\end{array}$ \\
\hline
\end{tabular}




\begin{tabular}{|c|c|c|c|c|c|c|c|}
\hline Citation & Quality & Question & Search Strategy & $\begin{array}{l}\text { Inclusion/ } \\
\text { Exclusion Criteria }\end{array}$ & $\begin{array}{l}\text { Data Extraction and } \\
\text { Analysis }\end{array}$ & Key Findings & $\begin{array}{l}\text { Usefulness/Recommendation/ } \\
\text { Implications }\end{array}$ \\
\hline $\begin{array}{l}\text { review. JBI } \\
\text { Evidence } \\
\text { Synthesis, } 18 \\
(6), 1156- \\
1188 . \\
\text { https://doi: } \\
10.11124 / \mathrm{JBIS} \\
\text { RIR-D-19- } \\
00252\end{array}$ & & & $\begin{array}{l}\text { Theses, Conference } \\
\text { Proceedings) } \\
\text { The search was } \\
\text { limited to English } \\
\text { language and to } \\
\text { articles published } \\
\text { from January } 2008 \text { to } \\
\text { February } 2018\end{array}$ & & $\begin{array}{l}\text { review question and } \\
\text { objective. }\end{array}$ & \begin{tabular}{||l}
-Meta-Analysis: 5 \\
studies with total \\
oncology nursing sample \\
of n=900. The studies \\
used ProQOL for the \\
evaluation of \\
compassion satisfaction, \\
burnout, and compassion \\
fatigue. These studies \\
showed medium and \\
high levels of burnout \\
with a prevalence rate of \\
$56 \%(38-74 \%)$, and \\
compassion fatigue \\
prevalence rate of $60 \%$ \\
$(37-81 \%)$.
\end{tabular} & \\
\hline
\end{tabular}




\section{Appendix C}

Levels and Quality of Evidence Synthesis Table

\begin{tabular}{|c|c|c|c|c|c|c|c|c|c|c|c|c|c|c|}
\hline $\begin{array}{l}\text { Key: } \\
\text { A: High quality } \\
\text { B: Good quality }\end{array}$ & 1 & 2 & 3 & 4 & 5 & 6 & 7 & 8 & 9 & 10 & 11 & 12 & 13 & 14 \\
\hline $\begin{array}{l}\text { Level I: } \\
\text { Randomized } \\
\text { controlled trials } \\
\text { (RCT) or } \\
\text { Systematic } \\
\text { review of RCT }\end{array}$ & & & & & & & & A & & & & & & \\
\hline $\begin{array}{l}\text { Level II: Quasi- } \\
\text { experimental }\end{array}$ & & & & & & & & & & & & & & \\
\hline $\begin{array}{l}\text { Level III: Non- } \\
\text { experimental }\end{array}$ & & & & & B & B & $\mathrm{A}$ & & B & B & B & & B & B \\
\hline $\begin{array}{l}\text { Level IV: } \\
\text { Opinion of } \\
\text { respected } \\
\text { authorities or } \\
\text { national expert }\end{array}$ & & & & & & & & & & & & $\mathrm{A}$ & & \\
\hline $\begin{array}{l}\text { Level V: Quality } \\
\text { improvement }\end{array}$ & $\mathrm{A}$ & B & B & B & & & & & & & & & & \\
\hline
\end{tabular}

Legend:

1. Adimando, 2018

2. Blackburn et al., 2020

3.Craigie et al., 2016

4. Durkin et al., 2018

5. Klein et al., 2018

\section{Michael et al., 2019}

7. Ortega-Campos et al., 2020

8. Rajeswari et al., 2020

9. Sinclair et al., 2017

10. Sullivan et al., 2019
11. Wentzel \& Brysiewicz, 2017

12. Xu et al., 2020

13. Yilmaz et al., 2018

14. Zajac et al., 2017 


\section{Appendix D}

Synthesis Table: Common Themes Related to Intervention

\begin{tabular}{|c|c|c|c|c|c|c|c|c|c|c|c|c|c|c|}
\hline & 1 & 2 & 3 & 4 & 5 & 6 & 7 & 8 & 9 & 10 & 11 & 12 & 13 & 14 \\
\hline CF and CS & yes & yes & yes & yes & yes & yes & yes & yes & yes & yes & yes & yes & yes & yes \\
\hline $\begin{array}{c}\text { Increased } \\
\text { Awareness }\end{array}$ & yes & yes & yes & -- & yes & -- & yes & yes & yes & yes & yes & yes & yes & -- \\
\hline Mindfulness & -- & yes & yes & -- & yes & -- & yes & yes & -- & yes & yes & -- & yes & yes \\
\hline ProQOL & yes & yes & yes & yes & yes & yes & yes & yes & yes & yes & yes & yes & yes & yes \\
\hline
\end{tabular}

\section{Legend:}

1. Adimando, 2018

2. Blackburn et al., 2020

3.Craigie et al., 2016

4. Durkin et al., 2018

5. Klein et al., 2018

\section{Michael et al., 2019}

7. Ortega-Campos et al., 2020

8. Rajeswari et al., 2020

9. Sinclair et al., 2017

10. Sullivan et al., 2019
11. Wentzel \& Brysiewicz, 2017

12. Xu et al., 2020

13. Yilmaz et al., 2018

14. Zajac et al., 2017 
Appendix E

\section{SWOT ANALYSIS}

\begin{tabular}{|c|c|}
\hline \multicolumn{2}{|c|}{ SWOT Analysis } \\
\hline Strengths & Weaknesses \\
\hline $\begin{array}{ll} & \text { Leadership Support } \\
\text { - } & \text { Staff Support }\end{array}$ & $\begin{array}{ll}\text { - } & \text { Staff Workload } \\
\text { - } & \text { Lack of time for the staff to take breaks } \\
\text { - } & \text { Leadership Workload }\end{array}$ \\
\hline Opportunities & Threats \\
\hline $\begin{array}{ll}\text { - } & \text { Establishing a procedure for self-care during } \\
\text { COVID pandemic } \\
\text { - } & \text { Staff training for CF and CS } \\
\text { - } & \text { Increase staff awareness }\end{array}$ & $\begin{array}{l}\text { - } \quad \text { Increased cost of intervention } \\
\text { - } \\
\text { Placing the reputation of the unit and } \\
\text { organization at risk } \\
\text { - } \quad \text { COVID } 19 \text { pandemic }\end{array}$ \\
\hline
\end{tabular}




\section{Appendix F}

\section{Project Short-Term and Long-Term Objectives}

\begin{tabular}{|c|c|}
\hline Objectives & Goals \\
\hline Short term & $\begin{array}{l}\text { Creating a policy and procedure for nurses and staff to increase awareness } \\
\text { and prevent CF. }\end{array}$ \\
\hline Long term & $\begin{array}{l}\text { - } \text { Reduction in medication errors } \\
\text { - Increase in patient satisfaction } \\
\text { - Decrease in nurse turnover } \\
\text { The CF program will be available to other units in the hospital. It will also } \\
\text { be available for new hires and as a part of the nurses' annual competencies. }\end{array}$ \\
\hline Process & $\begin{array}{l}\text { - At the end of } 6 \text { weeks of implementation, a } 4 \text { week program will be } \\
\text { offered weekly for participants to reduce CF and increase CS. } \\
\text { - In the first } 2 \text { weeks after IRB approval, there will be a recruitment of } \\
\text { nurses who are going to participate in the ProQOL survey. }\end{array}$ \\
\hline Outcome & $\begin{array}{l}\text { - Short term: increase compassion satisfaction by } 10 \% \text { at the end of } \\
\text { the intervention. } \\
\text { - Intermediate: implement a CF program and policy to all hospital } \\
\text { units by the end of } 6 \text { months } \\
\text { - Long term: increase CS in the organization by } 20 \% \text { at the end of one } \\
\text { year. }\end{array}$ \\
\hline
\end{tabular}




\section{Appendix G}

\section{Project Schedule}

\begin{tabular}{|c|c|c|c|c|c|c|c|c|c|c|c|c|c|c|c|c|c|c|c|c|c|c|c|c|}
\hline & & 2780 & & & & & & & & $\mathrm{R} 78$ & & & & & & & & 7803 & & & & & & \\
\hline 忿 & $\begin{array}{l}\bar{y} \\
\frac{y}{0} \\
3\end{array}$ & $\frac{n}{y}$ & $\begin{array}{l}n \\
\frac{n}{8} \\
3\end{array}$ & $\frac{y}{y}$ & $\begin{array}{l}\frac{a}{4} \\
\frac{0}{3} \\
3\end{array}$ & $\begin{array}{l}= \\
\frac{x}{8} \\
3\end{array}$ & $\begin{array}{l}\frac{m}{4} \\
\frac{y}{3} \\
3\end{array}$ & $\begin{array}{l}n \\
\frac{n}{8} \\
\infty \\
3\end{array}$ & $\frac{\bar{y}}{8}$ & $\frac{n}{\frac{n}{2}}$ & $\begin{array}{l}n \\
\frac{4}{8} \\
3 \\
3\end{array}$ & $\frac{\pi}{3}$ & $\begin{array}{l}a \\
\frac{y}{8} \\
3\end{array}$ & $\begin{array}{l}= \\
\frac{y}{8} \\
3\end{array}$ & $\begin{array}{l}\frac{m}{4} \\
\frac{y}{8} \\
3\end{array}$ & $\begin{array}{l}n \\
\frac{n}{8} \\
\infty \\
3\end{array}$ & $\frac{\bar{y}}{3}$ & $\frac{m}{\frac{n}{4}}$ & $\begin{array}{l}n \\
\frac{x}{8} \\
3\end{array}$ & $\frac{\bar{y}}{8}$ & $\begin{array}{l}\frac{a}{8} \\
\frac{8}{3}\end{array}$ & $\begin{array}{l}= \\
\frac{y}{8} \\
3\end{array}$ & $\begin{array}{l}\frac{m}{4} \\
\frac{y}{8} \\
3\end{array}$ & $\begin{array}{l}\frac{n}{4} \\
\frac{y}{2} \\
3\end{array}$ \\
\hline Meet with preceptor & $\mathrm{x}$ & $\mathrm{x}$ & $\mathrm{x}$ & $x$ & $\mathrm{x}$ & $x$ & $\mathrm{x}$ & $x$ & $\mathrm{x}$ & $\mathrm{x}$ & $\mathrm{x}$ & $x$ & $\mathrm{x}$ & $\mathrm{x}$ & $x$ & $\mathrm{x}$ & $x$ & $x$ & $\mathrm{x}$ & $x$ & $x$ & $\mathrm{x}$ & $\mathrm{x}$ & $\mathrm{x}$ \\
\hline $\begin{array}{l}\text { Prepare project } \\
\text { proposal }\end{array}$ & $\mathrm{x}$ & $\mathrm{x}$ & $\mathrm{x}$ & $\mathrm{x}$ & $\mathrm{x}$ & $\mathrm{x}$ & $\mathrm{x}$ & $\mathrm{x}$ & & & & & & & & & & & & & & & & \\
\hline Literature Review & $x$ & $\mathrm{x}$ & $\mathrm{x}$ & $\mathrm{x}$ & $\mathrm{x}$ & $\mathrm{x}$ & & & & & & & & & & & & & & & & & & \\
\hline $\begin{array}{l}\text { Submit to USA EBP } \\
\text { Project Review } \\
\text { Council (EPRC) }\end{array}$ & & & & & & & & & $\mathrm{x}$ & & & & & & & & & & & & & & & \\
\hline $\begin{array}{l}\text { Submit to } \\
\text { organization's IRB }\end{array}$ & & & & & & & & & $\mathrm{x}$ & & & & & & & & & & & & & & & \\
\hline $\begin{array}{l}\text { Receive USA EPRC } \\
\text { approval }\end{array}$ & & & & & & & & & & & $\mathrm{x}$ & & & & & & & & & & & & & \\
\hline $\begin{array}{l}\text { Receive organization } \\
\text { IRB approval }\end{array}$ & & & & & & & & & & & $\mathrm{x}$ & & & & & & & & & & & & & \\
\hline $\begin{array}{l}\text { Meet with key } \\
\text { stakeholders }\end{array}$ & & & & & & & & & & & & $\mathrm{x}$ & & & & & & & & & & & & \\
\hline $\begin{array}{l}\text { Structure and conduct } \\
\text { champion training }\end{array}$ & & & & & & & & & & & & & $\mathrm{x}$ & & & & & & & & & & & \\
\hline $\begin{array}{l}\text { ProQOL pre- } \\
\text { intervention survey }\end{array}$ & & & & & & & & & & & & & & $\mathrm{x}$ & & & & & & & & & & \\
\hline $\begin{array}{l}\text { Start compassion } \\
\text { fatigue and } \\
\text { compassion } \\
\text { satisfaction } \\
\text { intervention } \\
\end{array}$ & & & & & & & & & & & & & & & $\mathrm{x}$ & $\mathrm{x}$ & $x$ & $\mathrm{x}$ & & & & & & \\
\hline $\begin{array}{l}\text { ProQOL post- } \\
\text { intervention survey }\end{array}$ & & & & & & & & & & & & & & & & & & & $\mathrm{x}$ & $\mathrm{x}$ & & & & \\
\hline Data analysis & & & & & & & & & & & & & & & & & & & & & $\mathrm{x}$ & $\mathrm{x}$ & & \\
\hline $\begin{array}{l}\text { Dissemination of } \\
\text { results }\end{array}$ & & & & & & & & & & & & & & & & & & & & & & & $\mathrm{x}$ & $\mathrm{x}$ \\
\hline $\begin{array}{l}\text { Celebration of the } \\
\text { EBP project }\end{array}$ & & & & & & & & & & & & & & & & & & & & & & & & $\mathrm{x}$ \\
\hline
\end{tabular}




\section{Appendix H}

\section{Permission to Use the ProQOL}

Thank you for your interest in using the Professional Quality of Life Measure (ProQOL). Please share the following information with us to obtain permission to use the measure:

Please provide your contact information:

Email Address

n.samuel@usa.edu

Name

Naveen Samuel

Organization Name, if applicable

University of St. Augustine for Health Sciences

Country

United States

Please tell us briefly about your project:

I am currently enrolled in the DNP (Doctor of Nursing Practice) program at the University of St. Augustine for Health Sciences and I am in my clinical practicum to implement an evidence-based practice (EBP) for compassion fatigue and compassion satisfaction. I need the ProQOL tool and resources to utilize it in my project.

What is the population you will be using the ProQOL with?

Nurses in a community hospital

In what language/s do you plan to use the ProQOL?

Listed here are the languages in which the ProQOL is currently available

(see https://proqol.org/ProQol Test.html). If you wish to use a language not listed here, please select "Other" and specify which language/s.

English

Arabic

French

Spanish

The ProQOL measure may be freely copied and used, without individualized permission from the ProQOL office, as long as:

You credit The Center for Victims of Torture and provide a link to www.ProQOL.org;

It is not sold; and

No changes are made, other than creating or using a translation, and/or replacing "[helper]" with a more specific term such as "nurse."

Note that the following situations are acceptable:

You can reformat the ProQOL, including putting it in a virtual format

You can use the ProQOL as part of work you are paid to do, such as at a training: you just cannot sell the measure itself

Does your use of the ProQOL abide by the three criteria listed above? (If yes, you are free to use the ProQOL immediately upon submitting this form. If not, the ProQOL office will be in contact in order to establish your permission to use the measure.)

Yes 
Thank you for your interest in the ProQOL! We hope that you find it useful. You will receive an email from the ProQOL office that records your answers to these questions and provides your permission to use the ProQOL.

We invite any comments from you about the ProQOL and the experience of using it at proqol@cvt.org. Please also contact us if you have any questions about using the ProQOL, even if you noted them on this form. Note that unfortunately, our capacity is quite limited so we may not be able to respond to your note: however, we greatly appreciate your engagement. 


\section{Appendix I}

\section{Professional Quality of Life Scale (ProQOL)}

Compassion Satisfaction and Compassion Fatigue

(ProQOL) Version 5 (2009)

When you [help] people you have direct contact with their lives. As you may have found, your compassion for those you [help] can affect you in positive and negative ways. Below are some questions

about your experiences, both positive and negative, as a [helper]. Consider each of the following questions about you and your current work situation. Select the number that honestly reflects how

frequently you experienced these things in the last 30 days.

$1=$ Never $2=$ Rarely $3=$ Sometimes $4=$ Often 5=Very Often

1. I am happy.

2. I am preoccupied with more than one person I [help].

3. I get satisfaction from being able to [help] people.

4. I feel connected to others.

5. I jump or am startled by unexpected sounds.

6. I feel invigorated after working with those I [help].

7. I find it difficult to separate my personal life from my life as a [helper].

8. I am not as productive at work because I am losing sleep over traumatic experiences of a person I [help].

9. I think that I might have been affected by the traumatic stress of those I [help].

10. I feel trapped by my job as a [helper].

11. Because of my [helping], I have felt "on edge" about various things.

12. I like my work as a [helper].

13. I feel depressed because of the traumatic experiences of the people I [help].

14. I feel as though I am experiencing the trauma of someone I have [helped].

15. I have beliefs that sustain me.

16. I am pleased with how I am able to keep up with [helping] techniques and protocols.

17. I am the person I always wanted to be.

18. My work makes me feel satisfied.

19. I feel worn out because of my work as a [helper].

20. I have happy thoughts and feelings about those I [help] and how I could help them.

21. I feel overwhelmed because my case [work] load seems endless.

22. I believe I can make a difference through my work.

23. I avoid certain activities or situations because they remind me of frightening experiences of the people I [help].

24. I am proud of what I can do to [help].

25. As a result of my [helping], I have intrusive, frightening thoughts.

26. I feel "bogged down" by the system.

27. I have thoughts that I am a "success" as a [helper].

28. I can't recall important parts of my work with trauma victims.

29. I am a very caring person.

30. I am happy that I chose to do this work. 
Note. From (C) B. Hudnall Stamm, 2009. Professional Quality of Life: Compassion Satisfaction and Fatigue Version 5 (ProQOL).

/www.isu.edu/ bhstamm or www.proqol.org. This test may be freely copied as long as (a) author is credited, (b) no changes are made, and (c) it is not sold. 


\section{Appendix J}

\section{Mindfulness Video Links by Name}

Session 1: direct link:

Breath Awareness

https://youtu.be/NLw3LwopIiQ

Description: This mindful practice is session 1 and works with cultivating breath awareness for those who are experiencing compassion fatigue. Run time: 9 minutes 45 seconds.

Session 2: direct link:

Body Scan

https://youtu.be/h_RC6RSdm-o

Description: This mindful practice is session 2 and works with cultivating physical awareness for those who are used to losing themselves while caring for others \& experiencing compassion fatigue. Run time: 8 minutes 31 seconds.

Session 3: direct link:

Loving Kindness

https://youtu.be/Vullipkmzr8

Description: This mindful practice is session 3 and works with cultivating loving kindness for yourself while simultaneously sharing loving kindness with others. Run time: 8 minutes 01 seconds

Session 4: direct link

Uncovering Your Own Needs https://youtu.be/LvaBSLN1HJI

Description: This mindful practice is session 4 and works with uncovering your own needs that can get buried while caring for everyone else. Run time: 10 minutes 36 seconds.

Caveat: Do not listen to these mindfulness sessions while driving or operating hazardous machinery. 
Appendix K

\section{Certified Health Coach License}

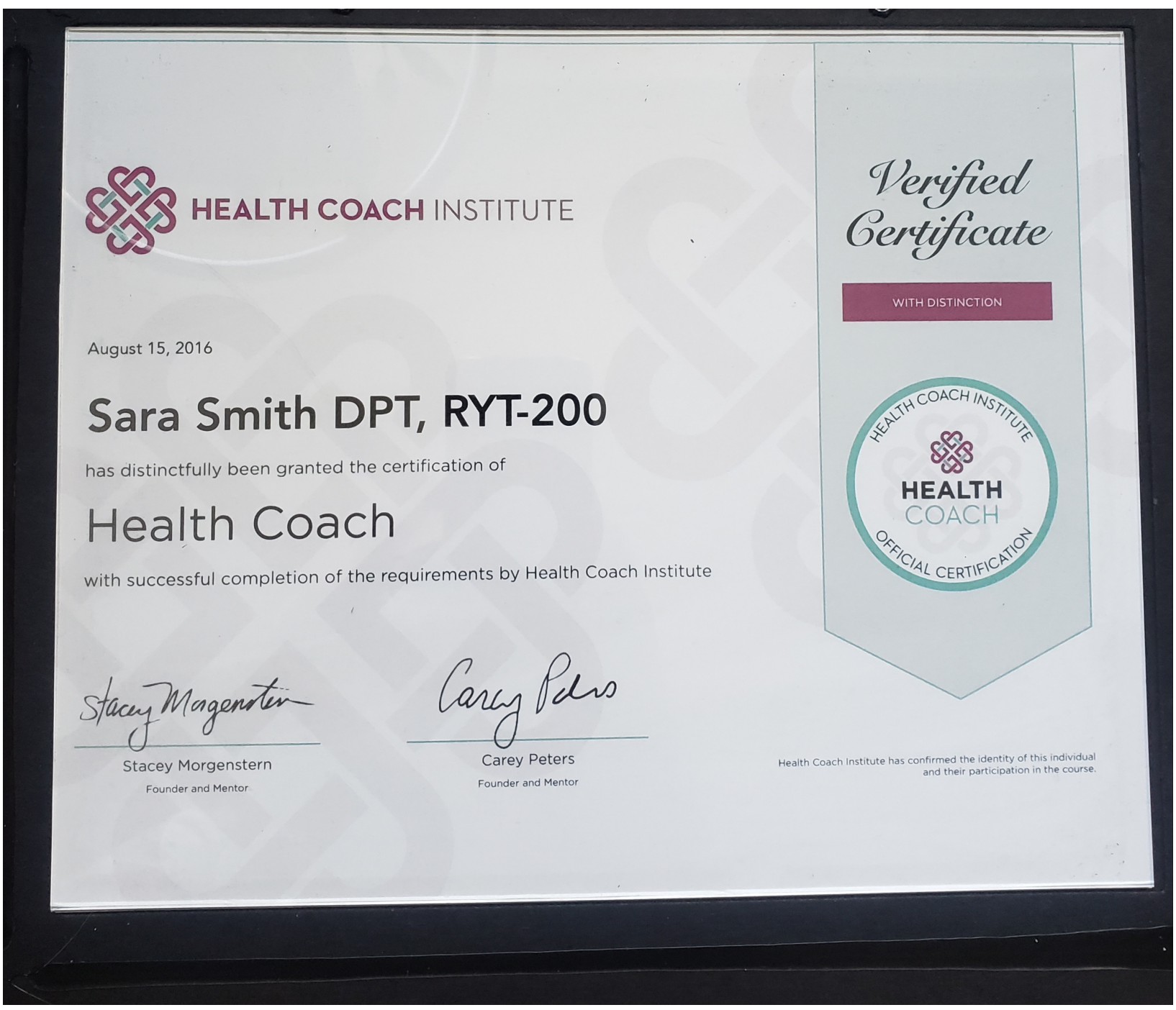


Appendix L

Data Collection Tool for Evaluation

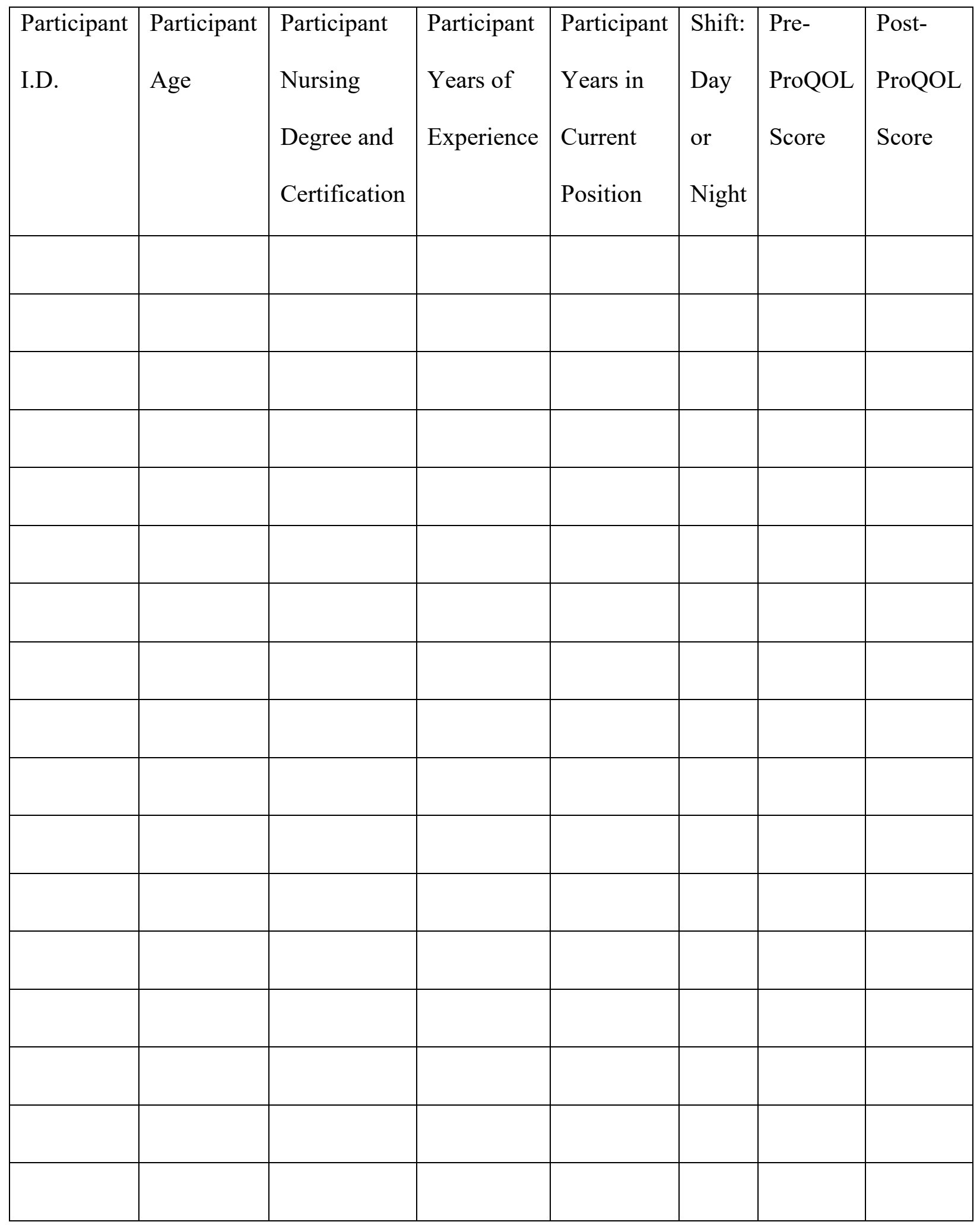




\section{Appendix M}

\section{Policy}

\section{Purpose}

Nurses who care for patients with acute and/or chronic illnesses are identified to be at risk to develop compassion fatigue. Compassion fatigue can lead to physical, psychological, and work-related consequences that may affect patient safety, patient care, and employee-employer engagement and relationship. Caregivers and helpers of all forms are at risk of harmful consequences; they may develop positive and negative feelings, such as compassion satisfaction and compassion fatigue, respectively. Compassion fatigue has two elements: burnout (BO) and secondary traumatic stress(STS). BO is accompanied by feeling exhausted, angry, and frustrated, while secondary traumatic stress is related to work trauma.

Bon Secours Mercy Healthcare recognizes the importance of the health and well-being of their employees. Reducing compassion fatigue and increasing compassion satisfaction will benefit the employer and their community because associates and dependents will be reaching peak performance both in and outside of the workplace. A policy to assess nurses' compassion fatigue and compassion satisfaction is well needed to offer nurses self-care and support.

\section{Policy}

Nurses and other healthcare workers will be given the opportunity to answer ProQOL to determine their compassion fatigue and compassion satisfaction levels as part of annual staff competency. Having a clear protocol will assist nurses and caregivers to minimize their risk of developing compassion fatigue and secondary traumatic stress. Early identification of compassion fatigue is the key to the early management and prevention of compassion fatigue. 
Nurses will be encouraged to practice mindfulness and self-care daily. Reminders will be sent in the weekly newsletter, staff meetings, and daily huddles. 


\title{
Appendix N
}

PowerPoint: Compassion Satisfaction (CS) and Compassion Fatigue (CF)

\section{Compassion Satisfaction and Compassion Fatigue}

\author{
NAVEEN SAMUEL, MS, ARNP, ANP-BC, FNP-BC \\ POST-PROFESSIONAL STUDENT \\ DOCTOR OF NURSING PRACTICE STUDENT \\ SCHOOL OF NURSING \\ UNIVERSITY OF SAINT AUGUSTINE FOR HEALTH SCIENCE
}

For more information see www.proqol.org

(C) Beth Hudnal Stamm, 2009 www.ProQol.org 


\section{vocabulary}

- Compassion Satisfaction

-Positive aspects for working as a helper

- Compassion Fatigue

-Negative aspects of working as a helper

$\checkmark$ Burnout

-Inefficacy and feeling overwhelmed

- Work-related traumatic stress

-Primary traumatic stress direct target of event

-Secondary traumatic exposure to event due to relationship with the primary person

(C) Beth Hudnal Stamm, 2009www.ProQol.org 


\section{Professional Quality of Life}

$\checkmark$ Compassion Satisfaction

- The positive aspects of helping

> "The good stuff"
> Compassion Fatigue

$>$ The negative aspects of helping

> "The bad stuff" 


\section{Compassion Satisfaction and Compassion Fatigue Model}

Figure 1: Bifurcated Model of Compassion Satisfaction and Compassion Fatigue

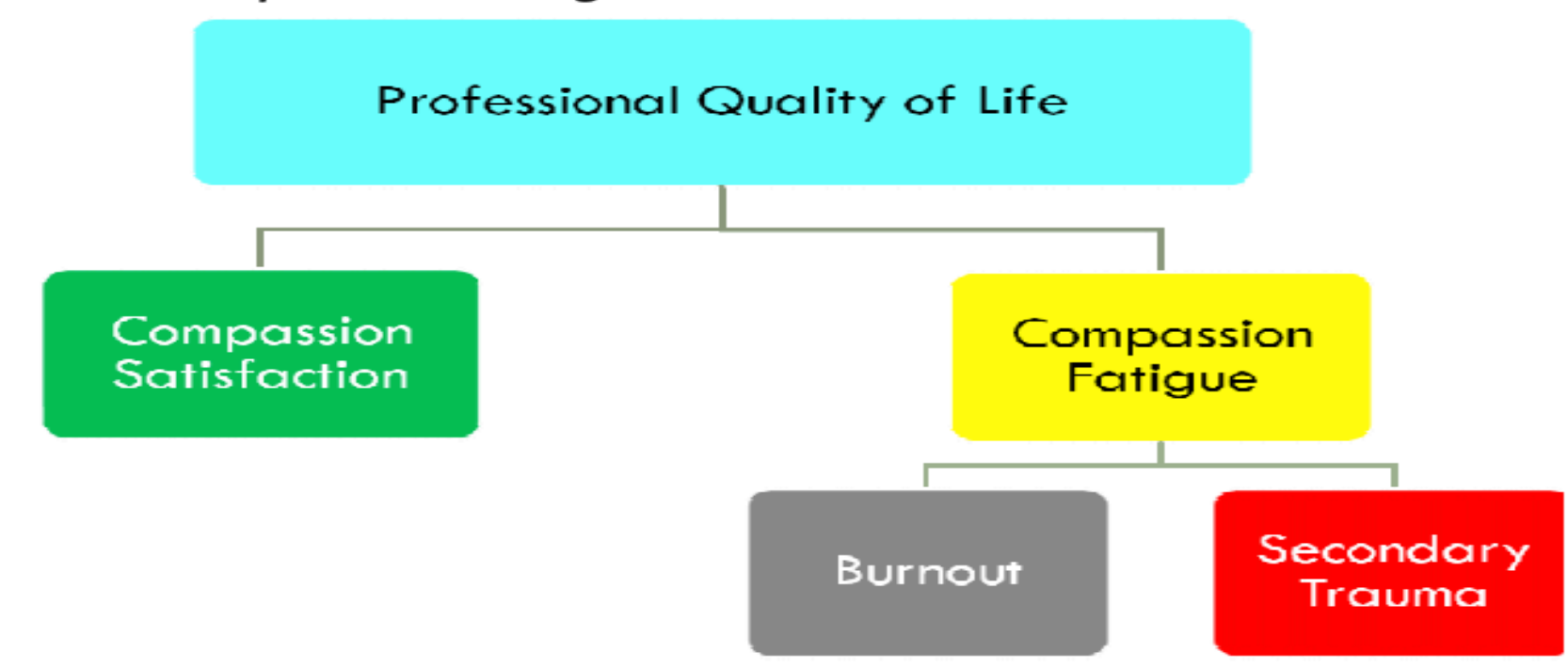

(C) Beth Hudnal Stamm, 2009 www.ProQol.org 


\section{Compassion Satisfaction}

- The positive aspects of helping

- Pleasure and satisfaction derived from working in helping, care giving systems

$\checkmark$ May be related to

-Providing care

-To the system

-Work with colleagues

-Beliefs about self

-Altruism

(c) Beth Hudnal Stamm, 2009 www.ProQol.org 


\section{Compassion Fatigue}

- The negative aspects of helping

- The negative aspects of working in helping systems may be related to

-Providing care

-To the system

-Work with colleagues

-Beliefs about self

$\checkmark$ Burnout

Work-related trauma

(C) Beth Hudnal Stamm, 2009 www.ProQol.org 


\section{Burnout and STS: Co Travelers}

$\checkmark$ Burnout

-Work-related hopelessness and feelings of inefficacy

$>$ STS

-Work-related secondary exposure to extremely or traumatically stressful events

$\checkmark$ Both share negative affect

-Burnout is about being worn out

-STS is about being afraid

(c) Beth Hudnal Stamm, 2009 www.ProQol.org 


\section{Relationships are complex}

- Multiple spheres

- Work environment

- "People helped" environment

- Personal environment

$\checkmark$ Positive (CS) \& negative (CF)

$\checkmark$ Altruism CS can override CF

- Compassion Fatigue two parts -Worn out (BO) common

-Frightened, traumatized (STS) rarer but powerful (c) Beth Hudnal Stamm, 2009 www.ProQol.org 


\section{Measuring CS \& CF: The professional Quality of Life Scale (ProQOL)}

- The ProQOL is free

- A 30 item self report measure of the positive and negative aspects of caring

- The ProQOL measures Compassion Satisfaction and Comapssion Fatigue

- Compassion Fatigue has two subscales:

- Burnout

- Secondary Trauma

- C Beth Hudnal Stamm, 2009 www.ProQol.org 


\section{Well Established}

- The ProQOL is the most widely used measure of the positive and negative aspects of helping in the world

- The ProQOL has proven to be a valid measure of compassion satisfaction and fatigue

It has been used for over 15 years

- The measure was developed with data from over 3000 people

(C) Beth Hudnal Stamm, 2009 www.ProQol.org 


\section{Easy to Use}

$\checkmark$ The ProQOL is easy to use

- It can be given individually or in groups

- It can be given online or at an individual computer

(c) Beth Hudnal Stamm, 2009 www.ProQol.org 


\section{Easy to Score}

- Full scoring

- More detailed and specific information but takes longer

- The simplified scoring

-Less specific but can be completed quickly and can be intuitively understood

-Good for training situations

(c) Beth Hudnal Stamm, 2009 www.ProQol.org 


\section{Resiliency Planning}

- Individual, personally

-The ProQOL can help you plan where to put your energy to increase our resilience

- Organizational planning

- Can help organizations find ways to maximize the positive aspects and reduce the negative aspects of helping

- Supportive supervision

-The ProQOL can be used as information for discussions

(c) Beth Hudnal Stamm, 2009 www.ProQol.org 
For More information:

WWW.PROQOL.ORG

Questions:

n.Samuel@usa.edu

Thank you

Note. From (C) Beth Hudnal Stamm, 2009 www.ProQol.org 


\section{Below are the things we want to let you know} about using the slides.

\section{You can}
1. Change the format.
2. Add your name and organizational information.
3. Add, rearrange, or remove slides to fit your
presentation.
4. Print them for handouts.
5. Copy them for sharing with others who are working with Compassion Satisfaction and Compassion Fatigue and related things.

\section{You cannot}

1. Sell the slides. We recognize that courses are for profit or the presenter takes a honorarium. This is not in violation of the use agreement on the slides. What is in violation is specifically selling the slides themselves.

2. Use them without proper credit. The copy right information is on the slides.

3. Use them without including the ProQOL.org website.

4. Use them in any way that is illegal or otherwise prohibited by an ethics or other oversight board that is associated with your activities.

5. Include them in any print or electronic media

publication that involves a copyright. Examples would be including them in a text book, a news article, a taped book, or a website. If you would like to use them in this way, we are usually

happy to provide permission to reprint.

Note. Permission to use PowerPoint from https://proqol.org/Customize_a_Presentation.html. 